\title{
Make-Believe: Parafiction and Plausibility
}

\section{Citation}

Lambert-Beatty, Carrie. 2009. “ Make-Believe: Parafiction and Plausibility.” October 129

(August): 51-84. doi:10.1162/octo.2009.129.1.51.

\section{Published Version}

doi:10.1162/octo.2009.129.1.51

\section{Permanent link}

http://nrs.harvard.edu/urn-3:HUL.InstRepos:26327087

\section{Terms of Use}

This article was downloaded from Harvard University's DASH repository, and is made available under the terms and conditions applicable to Other Posted Material, as set forth at http:// nrs.harvard.edu/urn-3:HUL.InstRepos:dash.current.terms-of-use\#LAA

\section{Share Your Story}

The Harvard community has made this article openly available.

Please share how this access benefits you. Submit a story.

Accessibility 


\section{Make-Believe: Parafiction and Plausibility*}

\section{CARRIE LAMBERT-BEATTY}

There is no steady unretracing progress in this life; we do not advance through fixed gradations, and at the last one pause: through infancy's unconscious spell, boyhood's thoughtless faith, adolescence, doubt (the common doom), then skepticism, then disbelief, resting at last in manhood's pondering repose of If.

But once again gone through, we trace the round again; and are infants, boys, and men, and Ifs eternally. Where lies the final harbor, whence we unmoor

no more?

- Herman Melville ${ }^{1}$

Istanbul, 2005

When the artist Michael Blum arrived in Istanbul to prepare for that city's Ninth International Biennial, he discovered that the apartment building that had been home in the early twentieth century to the teacher, translator, communist, and feminist Safiye Behar was slated for demolition. A remarkable, if little-known historical figure, Behar (1890-1965) was a Turkish Jew who enjoyed a long friendship_some say a romance-with Mustafa Kemal Atatürk, founder of the Turkish Republic. The two met in 1905, in the heady atmosphere of the Zeuve Birahanesi,

* Parts of this essay were presented at ThreeWalls Gallery and DePaul University in Chicago, and the Institute of Fine Arts, New York. Feedback from Huey Copeland, Blake Stimson, Jonathan Katz, Tom Williams, Claire Bishop, Eve Melzer, and Taylor Walsh, and readings by Helen Molesworth, Jennifer Roberts, and, especially, Julia Bryan-Wilson, helped me tremendously. An early version of some of this material was published in Talking With Your Mouth Full: New Language for Socially Engaged Art (Chicago: ThreeWalls Gallery and Green Lantern Press, 2008). Special thanks to Michael Blum, Walid Raad, and Aliza Shvarts, and to my students, particularly David Andersson, Austin Guest, Trevor Martin, and Jack McGrath. Finally, while working on this paper I had the benefit of reading Vered Maimon's important essay "The Third Citizen" published in the current issue of October. I hope that the conversation begun in these pages will continue beyond them.

1. Herman Melville, Moby Dick; or, The Whale (1851; New York: Penguin, 1986), p. 602.

OCTOBER 129, Summer 2009, pp. 51-84. (C) 2009 October Magazine, Ltd. and Massachusetts Institute of Technology. 
a bar owned by Safiye's father on the ground floor of the same now-crumbling building in the Beyoglu (then Pera) district of Istanbul. Throughout the last years of the Sultanate and early years of the Republic, Behar and Kemal maintained a correspondence both intimate and intellectual. The few surviving examples of their letters suggest Behar had considerable influence on the leader during this crucial period in Turkish history, particularly concerning the rights of women in the new republic. The friendship ended only with Kemal's death in 1938, the same year Safiye emigrated to Chicago. There she was active for many years as a translator of Turkish and an organizer for various leftist causes.

Blum, who trained as a historian at the Sorbonne before beginning his art practice, gave over his Biennial exhibition to the documentation of Behar's life. ${ }^{2}$ He constructed a modest but thorough historical house museum (necessarily displaced from the condemned building to an apartment complex- the "Deniz Palas," or "Palace of the Sea"-being used for the Biennial). Culling materials from various historical societies and archives, as well as from Behar's descendants, he set up vitrines featuring her letters, photographs, and books, and arranged original furnishings in the rooms of the apartment, to be peered at over Plexiglas barriers. He relayed Behar's life story with both bilingual didactics and a certain flair for stagecraft (a side table bore a dish of roasted chickpeas, Kemal's favorite snack). A video interview with Behar's grandson, Chicago architect Melik Tutuncu, brought her family legacy up to the present.

Recovering the forgotten life story and unacknowledged historical role of a female figure from an ethnic minority, this project, A Tribute to Safiye Behar, participates in a project of revision whose foundations are in the feminist and civil-rights movements of the 1960s and '70s. Splitting History into histories (and herstories), it also builds on the postmodern critique of metanarratives, while nodding to the discourses on identity and hybridity of the 1980s and '90s. Yet Blum's project was very much of its own moment. Under cover of the highly conventional visual language of the house museum, Blum was able to address two publics, and two political situations, at once. For the local, Turkish audience, the frank discussion of Mustafa Kemal's likely affair with the Jewish woman, and her influence on his reforms, served as a critical intervention in the official hagiography of the leader that continues to saturate public life in Turkey. The exposure of a previously repressed history signaled a critique of that state's penchant for secrecy (most infamously, its continuing denials of the Armenian genocide). Meanwhile, for the large contingent of international visitors brought to Istanbul by the Biennial in 2005-a moment when Turkey's potential membership in the European Union was being hotly debated-the life story of this secular, cosmopolitan, internationalist, and progressive woman, with her feminist organizing and her love letters in

2. Blum received a master's degree from the University of Paris Panthéon-Sorbonne, prior to attending the École Nationale de la Photographie in Arles. Born in Jerusalem, he is currently based in Vienna. 
French, cut into stereotypes about Turkey as backwards, other, and "Islamicist" (perhaps reminding them, for instance, that Turkish women had the right to vote earlier than their sisters in France). ${ }^{3}$

A Tribute to Safiye Behar, then, was both historical and political (and a suggestion that the former is inevitably the latter as well). But it was also something else again. For, arguably, the most substantial thing about the life of Safiye Behar is that Michael Blum made it up.

To some viewers, the fictionality of the installation's central figure was betrayed by details like the imperfectly pasted-on cover of the book of Nazim Hikmet's poetry on which Behar was credited as translator, or the coincidence that her face, blurred, blocked, or remote, could never quite be made out in any of the group photographs on display. 4 There is also a trace of overacting in the video, and a touch of dark humor, as when Safiye's grandson describes the death of his entire immediate family in a freak accident in 1966-a convenient tragedy for Blum, whose research might otherwise have gone on forever (and a personally coincidental one, since that is also the year of his own birth). But though subtle clues were planted, the display was meant to be convincing. While several writers on the exhibition chose to reveal the fiction, some otherwise astute critics seemed to accept the exhibition's claims, finding Safiye Behar a fascinating figure but the artwork itself flat-footed. 5 Turkish press reaction varied according to the media outlet. The progressive Radikal ran a supportive interview with the "Austrian historian" about Safiye and her importance to Turkish history, and only at the very end of the long piece revealed that she was a fiction, recategorizing Blum as an artist. ${ }^{6}$ In other publications, the ideological threat of this project to both Kemalist and Islamicist conservative forces in Turkey was registered more clearly (one writer joked that only Behar's fictionality saved her from assassination). ${ }^{7}$ For his part, Blum always maintained, if pressed, that Behar was "real to me." Curators and official exhibition publications kept the question open, ${ }^{8}$ and

3. It intervened in yet another way when the project was exhibited at the National Museum of Contemporary Art, Athens, in 2006.

4. Additionally, knowledgeable viewers knew something was amiss when they learned that one of Behar's sons married a granddaughter of (the childless) Emma Goldman.

5. Reviews of Blum's installation include: Elena Crippa, "Michael Blum, A Tribute to Safiye Behar, 2005, 9th Istanbul Biennial," e-cart 7 (March 2006), at http:// www.e-cart.ro, accessed May 1, 2008 ; T .J. Demos, "9th International Istanbul Biennial," Artforum 44, no. 3 (November 2005); Alison Carroll and Caroline Williams, "Istanbul Biennale," Artlink 26.

6. "Atatürk's lover Safiye," Radikal, August 28, 2005. I am grateful to Merih Uz for research assistance on the Turkish press reaction, to Ünver Rustem for English translations, and to both of them for informative discussions during my research on the Behar project. All Turkish translations are by Rustem.

7. Entry on Safiye Behar in the online alternative encyclopedia Sourtimes/Ekflisözlük, posted by username terranovanian, October 9, 2005.

8. Vasif Kortum, Biennial co-curator, says that he tended to present the story as fact; if the question arose he would go no further than calling Safiye "probable." E-mail to the author, May 21, 2009. According to co-curator Charles Esche, Blum and the Biennial staff sometimes replied to inquiries about Safiye's facticity by saying "well, she isn't documented," a phrase that emphasizes the limitations of the historical record while allowing the questioner to assume what she would about whether that meant Safiye-or someone like her-had or had not lived (while evoking immigration politics, which are germane to Safiye's story). Esche remembers sometimes saying that he wasn't sure himself whether Behar was fictional, since "by that stage Safiye had a life of her own." Charles Esche, e-mail to the author, April 1, 2009. 
she has acquired a kind of actuality in the years since: a newspaper article mentioned her among other historical figures, with no apparent awareness of her connection to Blum or to art at all; 9 the building she is supposed to have lived in (which has yet to be demolished) is known in the neighborhood as "the house of Safiye Behar."10 As for ordinary viewers at the Biennial, it appears that reactions to the installation varied, with some taking the exhibit at face value and others questioning its facticity to various degrees. One critic describes viewers "scurrying back" to revisit the installation once they heard that Safiye was an invented character. ${ }^{11}$

The shorthand I propose for discussing Blum's project is the parafictional. ${ }^{12}$ Fiction or fictiveness has emerged as an important category in recent art. But, like a paramedic as opposed to a medical doctor, a parafiction is related to but not quite a member of the category of fiction as established in literary and dramatic art. It remains a bit outside. It does not perform its procedures in the hygienic clinics of literature, but has one foot in the field of the real. Unlike historical fiction's fact-based but imagined worlds, in parafiction real and/or imaginary personages and stories intersect with the world as it is being lived. Post-simulacral, parafictional strategies are oriented less toward the disappearance of the real than toward the pragmatics of trust. Simply put, with various degrees of success, for various durations, and for various purposes, these fictions are experienced as fact.

9. This article appeared May 16, 2008, in the newspapers Vakit Haber and Bugün and the online news outlet Haber 7, with Irfan Dumlu cited as author in Bugün.

10. Thanks to Betsey Robinson and Ioli Kalavrezou, who discovered this when they went to look for the building in 2008.

11. Marc Spiegler, "Istanbul Biennial," Art Review 3, no. 12 (December 2005/January 2006), p. 141. One Turkish viewer's report of having been taken in by the exhibition is in the Behar entry in Sourtimes/Ekflisözlük (username empas kumpas, posted November 24, 2005).

12. I mean the term "parafiction" differently than the way it is sometimes used in literary studies to designate true stories told in the style of fiction. I'm indebted to the concept of the "paratheatrical" as discussed by Bruce Wilshire ("The Concept of the Paratheatrical," TDR 34, no. 4 [Winter, 1990], pp. 169-78), from whom I borrow the analogy to the paramedic ("paratheater" is a term generally associated with Jerzy Grotowski). Perhaps closer to the current discussion is the term "superfiction" used by the artist Peter Hill, though his is a broader category (see www.superfiction.com). My use of "parafiction" differs from that of literary critic James Rother in the 1970s, in discussions of writers such as Barthelme or Pynchon, whose work he described as "para-" in the sense that it referred to or built itself on previous fiction, understanding language as self-multiplying and non-referential, and history as a sea of texts that "disguise the ongoing impersonation of truth, deny that what is being said yields no recapturable past." ("Parafiction: The Adjacent Universe of Barth, Barthelme, Pynchon, and Nabokov," boundary 2, 5, no. 1 [Autumn, 1976], pp. 20-44, 42). As I'll suggest below, I believe the contemporary cases I'll describe depart from postmodernist visions like this one that have been taken to imply historical, epistemological, or ethical relativism. I agree with Michael Nash and Okwui Enwezor, who in their various writings on mixtures of fiction and documentary in contemporary art have suggested that such experiments actually defend against notions of failure of reference-see note 14 below. Rosalind Krauss mobilized the term "paraliterary" in the early 1980s to define a space for work which "cannot be called criticism," but also cannot "be called not-criticism": the writing of Barthes and Derrida, which put the distinction between literature and criticism under erasure. Though the issues at stake here are somewhat different, her model is particularly useful for Blum's kind of parafiction in particular: it's not history, but can't be called not-history ("Poststructuralism and the Paraliterary," Originality of the Avant Garde and Other Modernist Myths (Cambridge, Mass: MIT Press, 1983), pp. 291-95. 

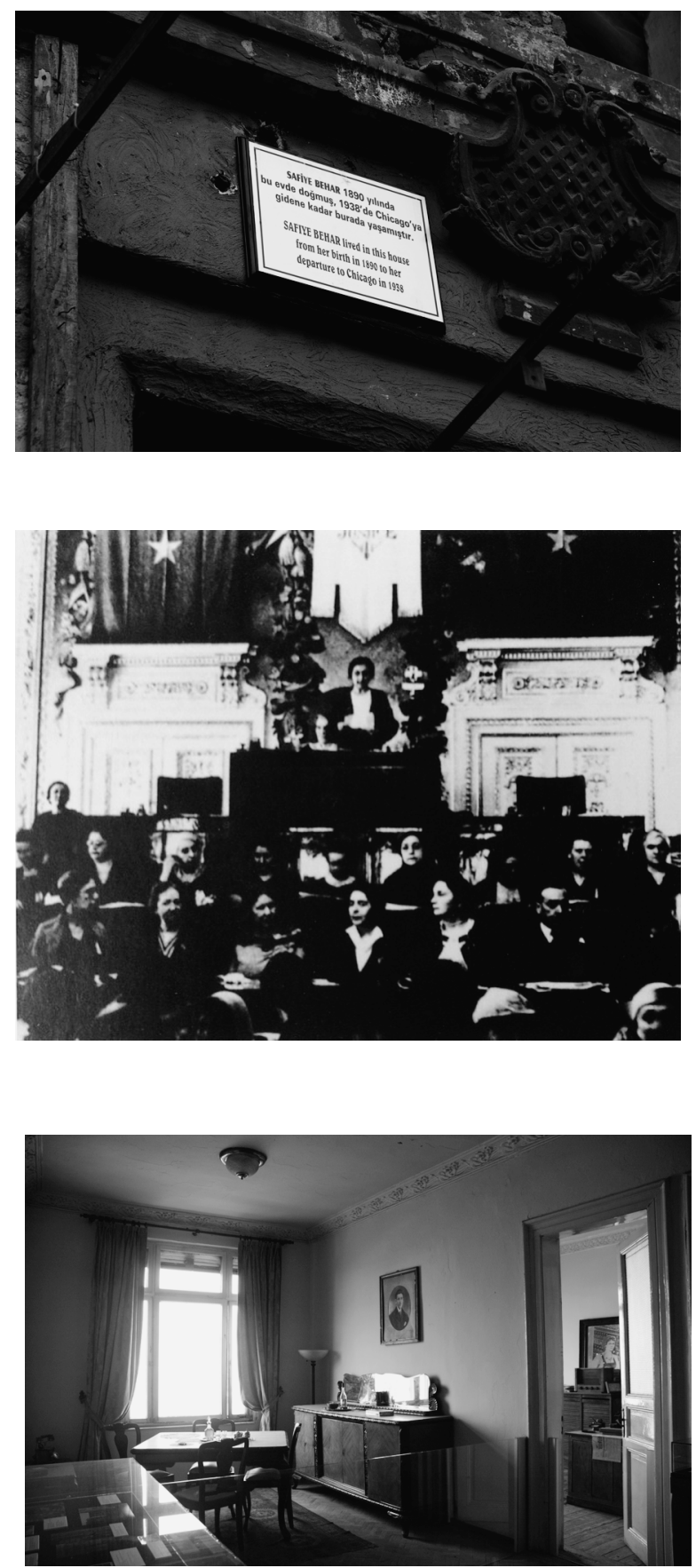

Michael Blum. A Tribute to Safiye Behar. 2005. From bottom: house museum installation; Safiye delivering speech at the 12th Women's Congress, Istanbul, April 1935 (Collection Women's Library and Information Center, Istanbul); plaque at site of Safiye's home, Hamalbasi Caddesi No. 18, Beyoglu. 
They achieve truth-status-for some of the people some of the time, as parafiction pioneer P. T. Barnum might have said.

All of which may be a nice way to say that a parafiction is a deception. Blum's project deceived tactically, and for progressive purposes, and in a way that allows for the possibility of the deception's discovery. But it deceived nevertheless, allowing viewers to be caught in a "gotcha" moment of having been fooled, to wonder uncomfortably about the status of the claims the exhibit made, or to go away in a strange kind of educated ignorance, their worldviews subtly altered-perhaps in truthful ways-by untruths. Exploring this mode, Blum was far from alone. ${ }^{13}$ Between 1998 and 2008, artists gave us advertising campaigns for imaginary products, a not-really-censored exhibition, hacked museum audio tours, several never-made movies, a sham supermarket, nonexistent video installations, dubious abortions, a staged marriage proposal, an impersonated Pope, ersatz archives, questionable military units, a faked vacation, an invented critic, a fictional historian, a made-up monkey, an arguably authentic rabbit, a projected penguin, and legions of fake artists, both historical and contemporary (twenty-seven in the recent pseudocollaborative EU portrait by Czech artist David Cerny alone). ${ }^{14}$ More generally, we've seen the term "intervention" supersede "resistance" in discussions of political art, valorizing modes like the parafictional that act disruptively outside the artistic context, ${ }^{15}$ while in the wider culture, fiction-in-the-real has become the characteristic mode of political humor for our time, with Sasha Baron Cohen, The Daily Show, and Brass Eye perfecting a technique in which parodists pass as their real counterparts, interacting with unsuspecting subjects whose gullibility, pompousness, stupidity, racism, extremism, or simple greed for the spotlight is then mercilessly exposed.16

If such experiments have become unusually pervasive in this period, it's no wonder. Here's another list of parafictions:

Fake rationales for war, a fake President dressed as a fake soldier declaring a fake end to combat and then holding up a fake turkey. An action

13. In the 2005 Istanbul Biennial related works included Khalil Rabah's Palestine Before Palestine, an arrangement of objects displayed in the style of a natural-history museum, all carved of olivewood, and Phil Collins's reunion of Turkish reality-TV participants.

14. The parafictional cuts through contemporary culture at a different angle than the category of the faux or partly fictionalized documentary, though this phenomenon is certainly related; the parafictional might be characterized as the performative version of "the documentary turn." See, among others, Michael Nash Experiments with Truth: The Documentary Turn (Philadelphia: FWM, The Fabric Workshop and Museum, 2004); Okwui Enwezor, “Documentary/Verité: The Figure of 'Truth' in Contemporary Art," in Experiments with Truth: The Documentary Turn; Mark Nash, "Reality in the Age of Aesthetics," Frieze 114 (April 2008). Other overlapping or related categories are Hal Foster's "Archival Impulse," (October 110 [Fall 2004]), Mark Godfrey's "Artist as Historian," (October 120 [Spring 2007]), David Joselit's theorization of avatars (see "Navigating the New Territory: Art, Avatars, and the Contemporary Mediascape," Artforum 43, no. 10 [Summer 2005]), Nato Thompson's "Strategic Visuality," (Art Journal 63, no. 1 [Spring 2004]), and Caroline Jones's "aesthetics of doubt," ("Doubt/Fear," Art Papers 29, no. 1 [January/February 2005]).

15. Not all interventions are parafictional, but all parafictions are in some way interventionist. The term emerged most influentially in Nato Thompson's exhibition The Interventionists: Art in the Social Sphere at MassMoCA (May 2004-March 2005).

16. Along with less political prank- and/or hoax-based entertainments in the Candid Camera tradition. 
movie star became governor and the government started making its own action movies, casting real soldiers like Jessica Lynch as fake combat heroes and dressing up embedded journalists as fake soldiers.

This catalogue of events from 2003 is just part of Canadian journalist Naomi Klein's sad litany in support of her claim that it had been "the year of the fake."17 Every modern period may consider itself less honest than the ones preceding, but Klein is not alone in feeling that the first decade of the twenty-first century has special claim to being, if not a more lie-prone era, then one in which untruths have had especially catastrophic effects. The slew of recent writings trying to describe or explain this condition ranges from philosophical explorations of "the ethics of the lie," to moralist warnings about our entry into "the post-truth era" to impassioned calls for renewed personal and public honesty. ${ }^{18}$ In this period, partisans in the US made a sport of cataloguing one another's deceptions (two titles were Liberal Lies and Lies and the Lying Liars Who Tell Them). Time magazine ran the headline "Untruths and Consequences" on its cover in July 2003, over an image of President Bush; two years later a much-needed term was added to the philosophical lexicon, when satirist Stephen Colbert identified Bush's characteristic mode of "truthiness"- truth measured by conviction rather than accuracy.

Of course, periodization itself is a kind of fiction, and parafiction is hardly an invention of the past decade. Contemporary instances like Blum's trail long legacies of hoax, prank, blague, Trickster myth, and parody. Even within more recent history there is a whole series of questions to be asked about the relation of this work to its precedents (in Dada, in conceptual art and performance, in the brilliantly undecidable actions of Andy Kaufman, in the Invisible Theatre of Agusto Boal, and in prankster activism from the Situationists to Abbie Hoffman to ACT-UP). Andrea Fraser's docent tours were in this mode (ahead of the curve, she gave them up in 1998), while related tactics in work by Fred Wilson, Cheryl Dunye, and Zoe Leonard allowed them to imagine the lives of marginalized historical individuals while simultaneously marking their erasure from the historical record. ${ }^{19}$ Of course, Marcel Duchamp lurks behind all of these examples, and whether or how this recent work re-imagines his legacy is an open question. Here, however, I am primarily interested in a horizontal history, mapping connections

17. Naomi Klein, “The Year of the Fake," The Nation, January 26, 2004. Though Klein's list sounds a bit like one Baudrillard could have made, I'll be suggesting that the more characteristic deceptions of the recent past are performative: rather than a representation with no original, we are beset by attempts to launch something false into quasi-truthfulness.

18. Jean-Michel Rabaté, The Ethics of the Lie (New York: Random House, 2008); Ralph Keyes, The PostTruth Era: Dishonesty and Deception in Contemporary Life (New York: Macmillan, 2004); Ihab Hassan, "A Plague of Mendacity: A Plea for Truth, Trust, Altruism," http://ihabhassan.com/bibliography (version of essays in Cream City Review 28 [2004] and in An ABC of Lying: Taking Stock in Interesting Times, ed. Livio Dobrez, Patricia Dobrez, and Jan Lloyd Jones [Melbourne: Australian Scholarly, 2004]).

19. A note from director Dunye at the end of her 1996 film Watermelon Woman (which is about a filmmaker researching the life of the title figure, a black lesbian star of 1930s race movies) states the issue with perfect concision and ambiguity: "Sometimes you have to create your own history. The Watermelon Woman is fiction." 

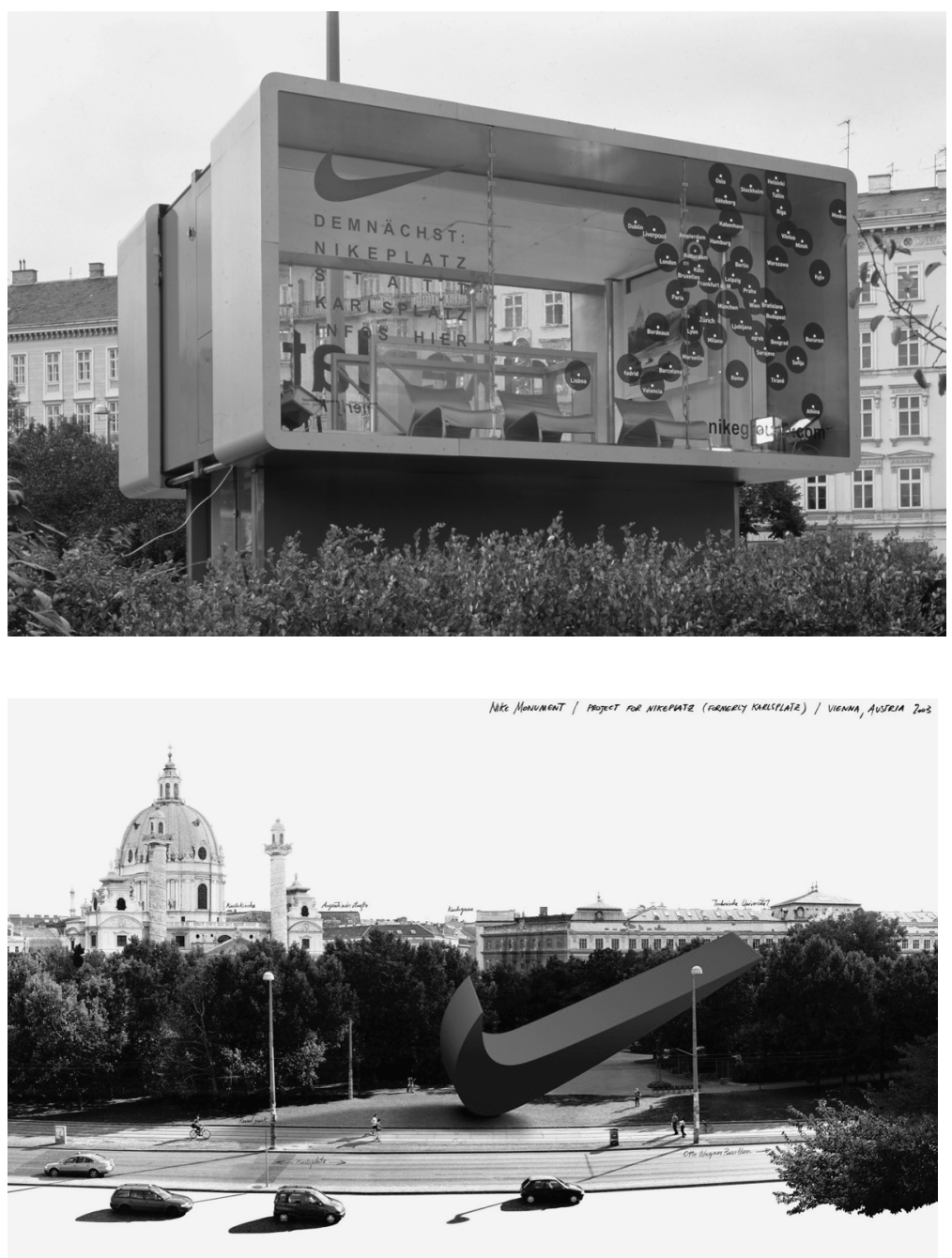

Top: 01.ORG (Franco and Eva Mattes) and Public Netbase. Nike Ground. 2003.

Bottom: 01.ORG. Rendering of proposed monument. 2003.

between experiments in dissimulation and linking them to certain broad historical shifts of the recent past. For despite their many precedents, parafictions interest me because they are so powerfully and uniquely appropriate to our historical moment-which is to say, powerfully and uniquely troubling. 
Vienna, 2003

One October night in 2003 a flatbed truck delivered a sleek orange-andwhite information booth to a plot of grass on the northeastern corner of Vienna's Karlsplatz. Printed on one of the booth's broad glass windows was a Nike "swoosh," a web address, and three words: "Nikeplatz (formerly Karlsplatz)." Visiting the URL, accepting one of the flyers distributed the next morning, or entering the booth to talk to Nike representatives, one learned that much as cities have sold the naming rights of sports stadiums to corporate sponsors, Karlsplatz would soon be changing its name. A monumental swoosh sculpture would appear in the shadow of the Karlskirche in what would, as of January 1, be known as "Nikeplatz." As the slickly animated Web site put it: "You want to wear it, why shouldn't cities wear it too?" On the park side of the information booth, a schematic map of Europe had broken out in orange dots, indicating that the Vienna initiative was part of a new international campaign. A Nikestrasse, Nikesquare, Nikestreet, or Piazzanike was coming soon to a European city near you.

As reporters learned with their first calls to Nike Austria, however, none of this was the company's doing. The infobooth, Web site, and marketing campaign comprised an art work titled Nike Ground: a collaboration between the Italian artistic duo Eva and Franco Mattes, who go by the name 0100101110101101.ORG (hereafter, “01.ORG"), and the innovative Austrian new media/art platform Public Netbase. ${ }^{20}$

Many of the passersby interviewed by the artists simply shrugged: since companies like Nike were taking over cities anyway, some said, they might as well pay for the privilege.21 Part of this is a credit to the artists, of course. The design of

20. See Vera Tollmann, "Becoming Nike: The Fake Behind the Swoosh," trans. Timothy Jones, Springeren (April 2003, net section); 01.ORG's Web site on the project at http:// www.0100101110101101.org/home/nikeground/intro.html, which provides links to international media coverage of the intervention and a link to an archived version of the project website nikeground.com; and "An Interview with Franco and Eva Mattes aka 01.ORG," (Culture Jamming, http://www.culturejamming.de/interviewIIe.html). Clemens Apprich, "Intermission at the Combat Zone: A Review of Public Netbase's Urban and Symbolic Lines of Conflict," Public Netbase: Non Stop Future: New Practices in Art and Media (Frankfurt: Revolver, 2008), online edition at nonstop-future.org; Brian Holmes, "Let it RIP: Obituary of an Endless Myth: Public Netbase, 1994-2006," Netbase / t0: Institute for New Culture Technologies, http://www.netbase.org/t0/intro/04.

21. Nike Ground illustrates both the power and the problems of culture jamming, the genre of "symbolic guerrilla warfare" (Eco) that emerged as an important form of activism in the 1990s. Culture jamming is generally oriented against corporate globalization, but typically focuses on its manifestations in the global North, such as the commercialization of public space, the loss of local specificity, or the depletion of values like originality and rebellion when they become so many advertising slogans. Its most frequent form is "subvertising," attempting to undermine a corporate brand's meaning and value with semi-convincing manipulations of its visual identity (paradigmatically, billboard alteration, like the Billboard Liberation Organization's subtle edit of an Apple ad sporting the visage of the Dali Lama, from "think different" to "think disillusioned"). Often knowingly drawing on Dada, especially the critical photomontages of John Heartfield, as well as situationist détournement, culture jamming expresses_-and stimulates-a desire for freedom from commerce's incursion into mental and physical landscapes. It consolidates identities and collectivities around an anti-corporate perspective, and it can be a kind of gateway to critiques of labor conditions, environmental damage, and other less symbol- and humor-friendly corporate affronts. On the other hand, given that exposure is a crucial part of branding, and that the youth-oriented brands most 
the Web site was spot-on, and the infobooth itself-crisp, sleek, rounded, and bright - was both outrageously out of key with the historic Viennese buildings surrounding it, and perfectly attuned to the visual rhetoric of design and marketing circa 2003. The crucial skill for parafiction is stylistic mimicry-as in Blum's channeling of the aesthetic of historical house museums. While parodists have always known how much style matters, as net artists, 01.ORG had pioneered a mode of parafiction that made it clear how much more this would become the case in our current information environment. One of their first projects, done in collaboration with Luther Blisset in 1998, was a convincing clone of the Vatican's Web site at the URL vaticano.org, in which, among other alterations, acceptance of abortion was worked into archived encyclicals. ${ }^{22}$

The Nike map with its colored dots has a certain martial feel, and the idea of a triumphant foreign entity redubbing place names in a European city has similar connotations, but given the ubiquity of the logo in sports and on the street, Nike's effort to occupy Karlsplatz didn't strain credulity too far (the corporation's flagship stores are called Niketowns, after all, already indicating a certain territorial ambition).23 In the age of lifestyle branding and guerrilla marketing the Nikeplatz idea was different from actual tactics in degree, not in kind. Its point was not how many people would accept the campaign as real (though many did) but how much they-and we-have already accepted about the takeover of public space by commercial interests. It's relevant here that Karlsplatz was and remains known as a hangout for drug dealers and addicts. Bold plans to revitalize the area as a cultural hub had recently been scrapped (to great protest by Nike Ground collaborators Public Netbase). Citizens might well have been willing to let a corporation sanitize what the city couldn't or wouldn't, in what would have been only a slightly more literal version of Times Square-style bargains made in New York and other cities.

One unfazed pedestrian interviewed in 01.ORG's documentation says the renaming plan is "just the reality of the corporate world." Another allows that this sort of thing is "part of commercial life." For these viewers, the corporation's civic incursion was within the horizon of plausibility-part of capitalist common sense. So it was, too, for those critical passersby who reacted to the proposition with displeasure. A third class of viewers approached the infobooth skeptically, and those of us who encounter the work as documentation of a past intervention are flatteringly included in this group. (The knowing, superior position one takes in such second-degree experiences of parafiction is no doubt a part of their pleasure, and

\footnotetext{
likely to be subvertized generally want to ally themselves with the virtues of creativity, irreverence, and daring displayed in projects like Nike Ground, it is entirely possible that culture jammers help their targets more than harm them. This partially explains why most corporate giants don't take legal action against their mosquito-like tormenters.

22. "Luther Blissett" is an open-use pseudonym that began being used in Italy in the mid-90s, and continues to be associated with art-related pranks in Europe and elsewhere. A group of writers based in Bologna has published several novels under the name.

23. In debunking the Nikeplatz rumor, the city council cited a law on the books since WWII that makes it impossible to change street names in Vienna.
} 
possibly a limit on their efficacy.) The project functions differently for each of these groups; moreover, it creates movement between them. For instance, a viewer who accepted the renaming as inevitable and later discovered it was a fiction: she slips outside the consensus that the parafiction's plausibility illuminates-or rather, the consensus that it calls into being as such.

Like "I christen this ship," or "I do" in a wedding ceremony, the phrase "Nikeplatz (Formerly Karlsplatz)" on the information booth is a variant of the category of performative utterances. Specifically, it is a case of what J. L. Austin called the "unhappy performative"-speech acts that don't take. (If an actor in a movie says, "I now pronounce you man and wife," the speech act is not untrue, but "infelicitous.") 24 Parafictions in general are performative, where that is understood to mean that they effect or produce something rather than describe or denote it. They are unhappy performatives insofar as they, like the movie wedding, are only "make-believe." But insofar as they make someone believe, however temporarily or ambiguously, they trouble the distinction between happy and unhappy performativity.

Notably, 01.ORG didn't discuss its goals in terms of eliminating aggressive branding or curtailing privatization. Rather, most of the team's rhetoric was about their own right to use Nike's name and logo. The logic would seem to be this: since, with the rise of offshore and contracted manufacturing, the Nike corporation now arguably produces not shoes and shirts but ideas and feelings, and since those ideas and feelings live on our bodies, in our minds, and all over the surfaces of our cities, "Nike" belongs to us. If a private interest colonizes enough mental and physical space, perhaps it becomes quasi-public. 01.ORG's parafiction performed this proposition too. Whether it would prove to be felicitously or not was left in the hands of the corporation. In this case, Nike took legal action to shut the project down-which is to say, to police the public-private boundary that creative, aggressive marketing like its own has worked to collapse.

Sydney, 2002

This third story actually begins in the spring of 1999, when an experimental fiction writer and computer programmer who came to call himself Andy Bichlbaum and a new-media artist who became known as Mike Bonnano, then working together as the anti-corporate corporation ${ }^{\mathrm{TM}} \mathrm{ark}$, came into possession of the domain name GWBush.com. The upcoming US presidential election was to be the first in which the Internet would be a significant factor, and as primary season ramped up, Bush strategist Karl Rove had already attempted to forestall online opposition by buying up anti-Bush URLs like "bushsux.com."25 The ® ${ }^{\mathrm{TM}}$ ark

24. Austin, J. L., How to Do Things with Words: The William James Lectures Delivered at Harvard University in 1955, ed. J. O. Urmson and Maria Sbisà, 2nd ed. (London: Oxford University Press, 1976), p. 14.

25. He had also purchased domain names that the campaign might want so that they would not have to buy them back later from "cybersquatters." See Jim Puzzanghera, "Online Race for Political Domains: Bush Outpaces Gore in Snapping Up Sites,” San Jose Mercury News, June 7, 1999. 
team, however, demonstrated their more sophisticated relationship to the new technology and its emerging epistemology (and possibly their awareness of 01.ORG's Vatican project) in realizing that a seemingly boring, sanctioned, and official URL was a far more powerful weapon. The Web site they put up at GWBush.com didn't slam the candidate or break new, damaging stories. Visually mirroring the actual campaign site, and written with the same cheery braggadocio, its goal was to make the Bush campaign more transparent. It described how the self-proclaimed "ecology governor" presided over Texas as it became the most polluting state in the Union; or proposed amnesty for anyone incarcerated for drug possession who claimed, as Bush had, that he or she had "grown up."26

This was the beginning of a mode of radical parody that the artists call "identity correction." The next year, now known as the Yes Men, they put a copy of the World Trade Organization's Web site up at the address www.gatt.org, with similarly parodic changes. 27 This time, the "contact us" links on the fake site were occasionally used by people actually trying to communicate with individuals at the WTO, and it is then that the Yes Men took "identity correction" beyond the bounds of traditional parody.

They returned the messages. When an email invited the organization's president to speak at a conference, for instance, "he" would send his regrets, but suggest a subordinate he could dispatch instead. It is thus that Mr. Hanniford Schmidt participated in a Salzburg seminar on international trade law, and that Mr. Granwyth Hulatberi represented the WTO in debates with anti-corporate-globalization activists on CNBC's Marketwrap Europe at the time of the G8 protests in Genoa (proposing, among other things, a market in "Justice Vouchers" so that countries that don't abuse people could sell human rights credits to those that do).

This is correction in the sense of unveiling, making clear what the target is really like (according to the correctors). As 01.ORG did with Nike, aspects of the target's policies and beliefs are followed through to logical but exaggerated conclusions. Though they can be delicious to read about or watch for those who share the Yes Men's politics, the problem with these negative identity corrections is that they generally fail to inspire outrage. Though the Web sites themselves irritate the target entities, the speeches usually garner nothing more than bemusement (if that) from their primary audiences. And negative corrections have problems even in terms of rallying the sympathetic (for one thing, in their wake actual current conditions can seem relatively benign). The brilliance of the Yes Men, however, was to realize that they could also correct identities in the sense of repairing. In

26. The Yes Men, "Limits to Freedom," http://theyesmen.org/hijinks/gwbush; The Yes Men: The True Story of the End of the World Trade Organization (New York: The Disinformation Company, 2004), p. 14. Versions of the sites are archived at www.rtmark.com/bush.

27. After having their site shut down by their service provider due to threats from the WTO, they developed and released open-source software to automate the process of "funhouse-mirroring" any website (they called it, what else, "Reamweaver"). See www.reamweaver.com; Michael Conner, "I am the World Trade Organization ... Or Am I?," The Austin Chronicle, July 5, 2002; "Corporations that miss the joke and just repeat the lie," New Media Age, February 12, 2004. 


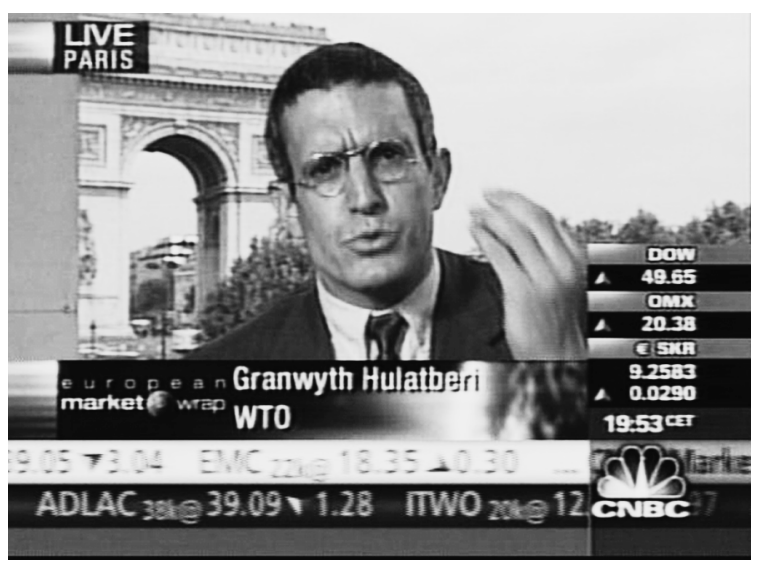

The Yes Men. End of the WTO. 2002.

positive identity correction, the target is made to announce strategies and transformations that are salutary from the point of view of the corrector, and that the actual person or entity must then choose to ignore or deny. 28

This brings us to Sydney in May 2002, when a WTO representative by the name of Kinnithrug Sprat arrived to address the Certified Practicing Accountants Association of Australia. He spent nearly an hour summarizing research that shows the failure of the WTO's operative principles: the link between cash-crop export and drought; the decrease in the income of the poorest forty percent of populations under trade liberalization; the failure of foreign direct investment to stimulate third-world economic growth. In light of this evidence, he explained, the WTO had decided to disband. It would reconstitute itself as the Trade Regulation Organization, an entity devoted to making trade "help people instead of businesses." 29

While the Yes Men's seemingly outrageous exaggerations of the WTO's actual stances had failed to get a rise out of audiences already aligned with its

28. On November 12, 2008 thousands of people in New York, Washington, and other cities received complimentary copies of The New York Times, with the bold headline, "Iraq War Ends." Co-created by The Yes Men, The Anti-Advertising Agency, Not An Alternative, CODEPINK, Improv Everywhere, "many others, and hundreds of volunteers," the "special edition" nodded to John Lennon and Yoko Ono's "War is Over (if you want it)" billboards of 1969-70, though here the parenthetical clause was implied simply by the preponderance of progressive visions in the headlines ("Maximum Wage Law Passed"; "Secretary Apologizes for W.M.D. Scare"). While the faux edition projected an ideal world in which the effects of the Bush years were rolled back, it got its special charge from the paper's initially convincing appearance. It certainly didn't fool anyone. But thinking of the money and effort put into writing a full newspaper's worth of stories in the right diction and style, printing it on newsprint paper of the right type and size, with the right ink and images, and then mobilizing hundreds of volunteers to hand it out in the streetrather than simply writing about the imagined changes in an essay or poem or blog-makes clear part of the difference between parafiction and other types of representation. There is surplus truth-value produced by that labor-a kind of performative residue. See www.nytimes-se.com.

29. The Yes Men, "End of the WTO," http://theyesmen.org/hijinks/sydney; Shane Wright, "Fed: WTO hoax snares Aust's CPA," AAP News Feed, 27 May 2002. 
basic principles, to their surprise this announcement of socially-progressive decisions that largely broke with those principles was met with marked enthusiasm, with accountants approaching Mr. Sprat after his talk, full of ideas for helping the "TRO" serve the people of the global South. Such converts were bound to be disappointed-but not before having had a concrete experience of the motto of the anti-corporate-globalization movement: "Another world is possible."

Here is how the Yes Men muse on the positive reaction to their most fantastically progressive proposals:

Could it be that the violent and irrational consensus gripping the world, what we call corporate globalization, is maintained only through a sustained and strenuous effort of faith? Could it be that almost everyone-even those, like accountants, that we are usually inclined to think of as conservative-would immediately embrace a more humane consensus if one were presented by those in positions of authority?

What they discovered is their ability to intervene in what Jacques Rancière calls the distribution of the sensible: the system of inclusions and exclusions that determine what can be sensed; the literally common sense about what can be said, thought, seen, felt, and who can say, think, see, and feel it. ${ }^{30}$ If a group of Australian accountants can suddenly find it thinkable - even credible, even actionable - to realign world trade to the benefit of indigenous people and the global poor, then something like a new distribution of the sensible has, at least temporarily, been brought into being.

In many cases, the difference between happy and unhappy performatives depends on the authority with which the speaker is vested (not only does the stage priest not really cause the two actors before him to become married, but in most of this country no one can wed two men or two women). A happy performative is usually an authorized one; moreover, part of what they performatively produce is that authority itself. But, following Derrida, poststructuralist thinkers have argued for the political potential of performativity by questioning Austin's absolute distinction between authorized and unauthorized speech, serious and nonserious contexts, happy and unhappy performatives. ${ }^{31}$ So does the parafictioneer. The Yes Men realized that the consensus around free-trade ideology could be changed by speech

30. Jacques Rancière, The Politics of Aesthetics: The Distribution of the Sensible, trans. Gabriel Rockhill (London: Continuum International Publishing Group, 2004). Though Rancière's stress on the commonality of politics and aesthetics in "the sensible" is generative it should be noted that the idea of an explicitly political work of art is a problematic one within his philosophy, where disruption of an existing configuration of the sensible is incompatible with meaningfulness or readability: it will always be caught between "the readability of the message that threatens to destroy the sensible form of art and the radical uncanniness that threatens to destroy all political meaning." (p. 63)

31. A few of the key texts for performativity theory are Jacques Derrida, "Signature, Event, Context" (1971), trans. Samuel Weber and Jeffrey Mehlman, in Limited, Inc (Evanston IL: Northwestern University Press, 1988); Judith Butler, Gender Trouble: Feminism and the Subversion of Identity (New York: Routledge, 1990) and Bodies That Matter: On the Discursive Limits of Sex (New York and London: Routledge, 1993); Eve Kasofsky Sedgwick and Andrew Parker, introduction to Performativity and Performance (New York and London: Routledge, 1995). 


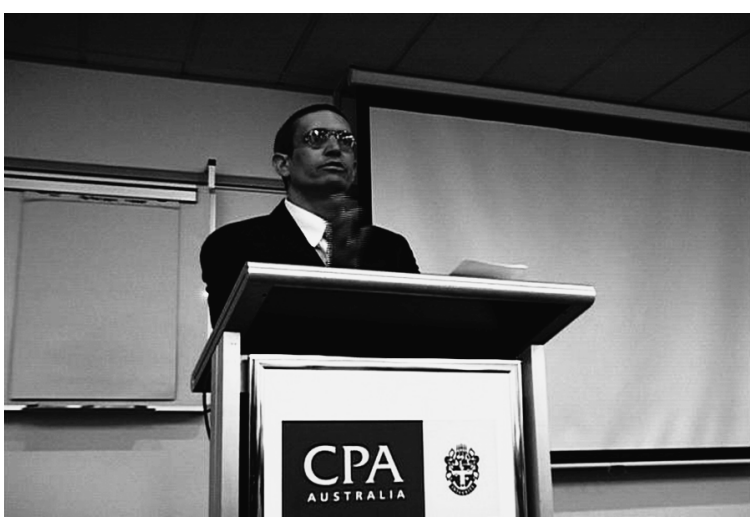

The Yes Men. Might Makes Right. 2001.

acts-as long as the speakers were "in positions of authority." They lacked such authority, but given a URL and a change of clothes, they could literally make-believe, convincing some people, some of the time, that they had it. ${ }^{32}$ This is, perhaps paradoxically, both to use and to undermine the authority they target. The Yes Men put it this way: "It seems people can accept just about anything if you're dressed in a suit."33

Toward the end of Gender Trouble, Judith Butler wrote that the seeming substantiality of gender is itself

... a constructed identity, a performative accomplishment which the mundane social audience, including the actors themselves, come to believe and to perform in the mode of belief .... Genders can be neither true nor false, neither real nor apparent, neither original nor derived. As credible bearers of those attributes, however, genders can also be rendered thoroughly and radically incredible. ${ }^{34}$

Here belief becomes the crux of the performative. The Yes Men play with the two sides of that realization. On the one hand, free-trade ideology and the authority of its proponents are denaturalized, made "radically incredible." On the other, the viewer's credence (and secondary audiences' witnessing of that credence) becomes a synapse between the imagined and the actual. ${ }^{35}$

32. Or one could say that they exaggerate the lack that is at the center of all identity, and the performative iterations that construe it as substantive. Such points aside, the Yes Men do speak as white men from the global North. To what degree is parafiction a sport of the privileged? On the other hand, the theory of performativity would be useful in a discussion of the camp and/or queer aspect of the Yes Men's pranks. Sarah Kanouse has made an argument about the phallocentrism of prank-based activism in "Cooing Over the Golden Phallus," Journal of Aesthetics and Protest 1, no. 4 (2005).

33. Dennis Roddy, "Liar's Poker," Pittsburgh Post-Gazette, December 12, 2004.

34. Butler, Gender Trouble, p. 141.

35. Earlier, 01.ORG demonstrated the role of belief in the performative, though problematically, when during their papal stint they freely granted e-pardons to petitioners who tried to contact the Pope through their fake Vatican website. When a priest says "I absolve you," your spiritual state has changed; when a few smartass artists say it, it has not. But if you believe you were pardoned by a priest, does it matter if it was 
Imagine a hypothetical viewer of A Tribute to Safiye Behar: a European tourist, vaguely opposed to Turkish accession to the EU, who takes the exhibit as purely factual and whose position is softened, to some degree, by the Turkish history she learns there. What happens when she discovers she has been duped? For some viewers, Safiye's shift into the category of fiction might harden previous prejudice. But the parafictioneer's gamble is that for other viewers, or perhaps even for the same ones at different psychological levels, the experience of having known Safiye as real would have a lingering effect even after the disillusionment. "The plausibility itself is very real," says Blum. ${ }^{36}$ The art of the plausible discloses consensus about the way things are; but it also can make a new reality sensible: accessible both to feeling and reason. It not only matches, but mobilizes Rancière's model of fictions as "material rearrangements of signs and images, relations between what is done and what can be done." 37

The efficacy of positive identity correction-and the poetry-turns on this power to shift something into the range of the plausible. Such shifts can be deeply moving. In what may be the most famous intervention by the Yes Men, a representative of Dow Chemical agreed to an interview on BBC World TV on the twentieth anniversary of the Union Carbide chemical spill at Bhopal, India, which devastated the region in 1984, killing at least twenty thousand people and sickening untold thousands more. Since Dow has categorically refused to take responsibility for cleaning up the environmental damage or compensating the victims since absorbing Union Carbide in 2001,38 it was a surprise to hear Dow's Jude Finisterra announce that the chemical giant had decided to make reparations to the victims and to remediate the toxic site, at a cost of 12 billion dollars, in what he called "the first time in history that a publicly owned company of anything near the size of Dow has performed an action which is significantly against its bottom line simply because it is the right thing to do." Even today, knowing that it only took the BBC two hours to detect and unveil the speaker as an imposter, it is electrifying to watch the text below the talking head change to "Breaking News: Dow accepts full responsibility" (as it was for Dow's stockholders, in a different way: its stock price immediately dipped). ${ }^{39}$ For those two hours, the world believed that there would be something like justice in Bhopal; for that time, there existed a different model for corporate decision-making, an ethical as well as financial bottom line.

But parafiction is itself ethically risky. As many have pointed out, the victims of Union Carbide in India were also among those taken in by Finisterra's

\footnotetext{
actually an imposter? For you it matters utterly (that's why this particular parafiction seems so cruel) while for the nonbeliever observing you it matters not at all (that's why it also seems relatively pointless).

36. Michael Blum, email to the author, March 23, 2009.

37. Rancière, Politics of Aesthetics, p. 39.

38. Some victims had received \$300-500 from Union Carbide in 1989, equivalent to five years of medical care, according to the Bhopal Medical Appeal (www.bhopal.org); Bhopalis continue to develop toxin-related illnesses twenty-five years later. Dow has a website, the "Bhopal Information Center," giving its positions at www.bhopal.com.

39. A clip is available on YouTube.
} 


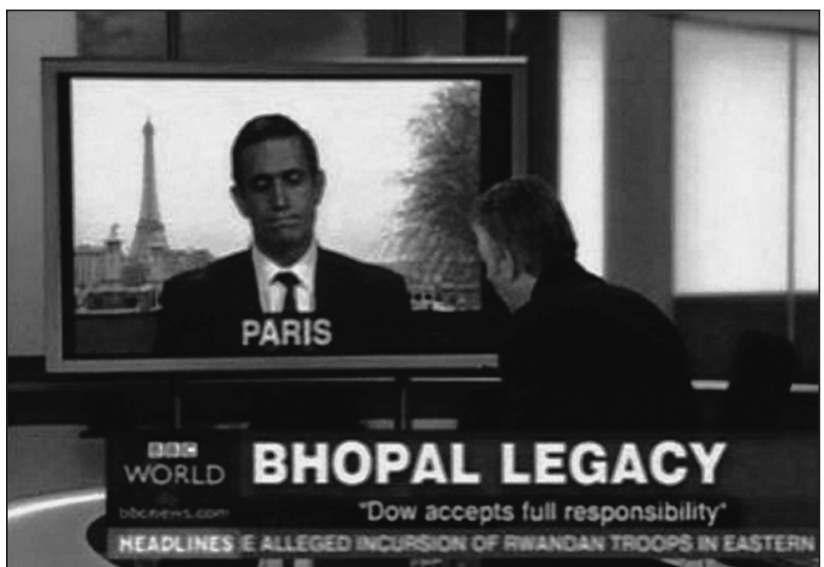

The Yes Men. Dow Does the Right Thing. 2004.

announcement (fitting that his name combined the patron saint of impossible causes and the world's end). One can only imagine their joy and corresponding disappointment when they learned that they still awaited justice. ${ }^{40}$ Moreover, from some points of view any purposeful deception is inherently injurious. Consider the argument, which Sisela Bok put in ecological terms in 1978, that “...trust is a social good to be protected just as much as the air we breathe or the water we drink." 41 Though the Yes Men may have outsmarted Rove in 1999, in some ways the work they went on to do is itself a "funhouse-mirror" of that operative's infamous techniques. Surely, the performativity they deploy is the jester's version of "We're an empire now, and when we act, we create our own reality." 42 Such similarities can lead you to side with Bok and others who call for a return to honesty in personal and political communication. Or they can leave you agreeing with the Yes Men that precisely in such a climate, "we need to be devious in order to achieve a condition of honesty." 43 (Just what social trust, after all, do we imagine we would preserve, in arguing against the use of deception in cultural-political

40. The Yes Men admit to "nagging doubt" about this and have apologized to the people of Bhopal. They have also responded semantically ("For 20 years, the victims of Bhopal falsely hoped that Dow and Union Carbide would do something to ease the suffering that they'd caused ... those who heard our announcement didn't falsely hope, they were falsely certain that their suffering was at long last over") and pragmatically: "If the deaths, debilities, organ failure, brain damage, tumors, breathing problems, and sundry other forms of permanent damage caused by Dow and Union Carbide aren't enough to arouse your pity, and the hour of "false hopes" we caused is-fantastic, we won! Go straight to Bhopal.net and make a donation." (http://theyesmen.org/faq).

41. Sissela Bok, Lying: Moral Choice in Public and Private Life, 2nd ed. (New York: Vintage Books, 1999), p. 26. The Yes Men are less ambivalent about this critique than the "false hope" charge. Since the BBC immediately and prominently retracted the story, they say, "There was no net misinformation. In fact there was significantly more information as a result, since more people knew about Bhopal and Dow, especially in the US" (http://theyesmen.org/hijinks/bbcbhopal).

42. Senior Bush adviser quoted by Ron Suskind in "Faith, Certainty and the Presidency of George W. Bush," The New York Times Magazine, October 17, 2004.

43. The Yes Men, "Frequently Asked Questions," http://theyesmen.org/faq. 
work?) For my part, I am ultimately not interested in passing ethical judgment on parafictioneers. But neither do I think the problems they raise can be put aside. The fact that parafictions are queasy-making is key to what they are and what they do.

New Haven, 2008

On Thursday, April 17, 2008, the Yale Daily News reported that the end-of-theyear student exhibition set to open the following Tuesday would include art major Aliza Shvarts's documentation of a nine-month-long senior project. According to a press release from the artist and an interview with reporters, during this time she had used donated sperm to inseminate herself as often as possible, while every month, on the twenty-eighth day of her menstrual cycle, she took herbal medications to induce miscarriage. 44 In the exhibition, videos of the artist experiencing vaginal bleeding were to be projected on four sides of a clear plastic cube, the walls of which would be infused with samples of the discharged fluid.

Had this multimedia sculpture existed alone (or existed at all?), the project might never have transcended the category of undergraduate art. But, as intended, Shvarts's real accomplishment was the drama that unfolded in the wake of her announcement. By 8 A.M. that day, six readers had posted comments about the Shvarts story on the Yale newspaper's Web site. ${ }^{45}$ By midnight there were two hundred and eighty-two. Gawker.com picked up the story at 10 A.M., and by afternoon reports of the "abortion artist" had echoed around the blogosphere, with mainstream media reporting the story in the days immediately following. ${ }^{46}$ Predictably, it incited especial fervor on conservative and anti-abortion Web sites. The president of the National Right to Life Committee called Shvarts a serial killer. ${ }^{77}$ On the ugliest fringe, anti-Semitic bloggers found ammunition in her actions (she received threat-

44. Martine Powers, "For senior, abortion a medium for art, political discourse," Yale Daily News, April 17, 2008. The statement Shvarts released read: "For the past year, I performed repeated self-induced miscarriages. I created a group of fabricators from volunteers who submitted to periodic STD screenings and agreed to complete and permanent anonymity. From the 9 th to the 15 th day of my menstrual cycle, the fabricators would provide me with sperm samples, which I used to privately self-inseminate. Using a needless syringe, I would inject the sperm near my cervix within 30 minutes of its collection, so as to insure the possibility of fertilization. On the 28th day of my cycle, I would ingest an abortifacient, after which I would experience cramps and heavy bleeding. To protect myself and others, only I know the number of fabricators who participated, the frequency and accuracy with which I inseminated, and the specific abortifacient I used. Because of these measures of privacy, the piece exists only in its telling. This telling can take textual, visual, spatial, temporal, and performative forms-copies of copies for which there is no original." This statement with additional paragraphs explaining her intentions was published as a guest column in the Yale Daily News on April 18, 2008. She had previously distributed the statement to members of her senior thesis class, her adviser, other faculty, and her college dean.

45. All eight initial responses denounced the work, though one writer did acknowledge Shvarts's freedom of expression.

46. Lexis Nexis's blog archive finds at least fifteen distinct English-language blog entries posted on April 17, and a hundred more by late May. Internet search engines find dozens more. The story was picked up by the mainstream news media on Friday, April 18, when it began to be reported by wire services, The Washington Post, New York Times, Newsday, Newsweek, and newspapers from Ireland to Australia and Korea.

47. http://www.foxnews.com/story/0,2933,351608,00.html. 
ening hate mail in this vein as well), ${ }^{48}$ even as others likened her to Mengele. ${ }^{49}$ But the artist came in for critique from the left as well. A NARAL spokesperson called the project insensitive and offensive, Yale pro-choice groups distanced themselves, ${ }^{50}$ and liberal bloggers worried (perceptively) that the project would only incite their opponents: "It's as if someone came up with a formula that incorporated all their favorite bugbears: Irresponsible sluts, frivolous abortions, liberal academia, and self-indulgent performance art." 51 A common theme for the more moderate opponents of her project was that the acts she described could have been physically and mentally harmful.52 And so, nearly across the board, there was condemnation of Shvarts's university for allowing it. 53

That same day, a university spokesperson issued a statement:

Ms. Shvarts is engaged in performance art. Her art project includes visual representations, a press release and other narrative materials. She stated to three senior Yale University officials today, including two deans, that she did not impregnate herself and that she did not induce any miscarriages.

The entire project is an art piece, a creative fiction designed to draw attention to the ambiguity surrounding form and function of a woman's body.

She is an artist and has the right to express herself through performance art.

Had these acts been real, they would have violated basic ethical standards and raised serious mental and physical health concerns. 54

48. http://newsfromthewest.blogspot.com/2008_04_17_archive.html, accessed March 1, 2009. Tellingly, Newsfromthewest, which appears to be completely de-dicated to virulent anti-Semitism, calls itself "the Internet's most dynamic truthsite." The language of unveiling truth and disabusing the deceived is everywhere in hate speech on the Internet (and of course long before it, from the Elders of Zion to Holocaust denial).

49. http://sigmundcarlandalfred.wordpress.com/2008/04/21/alicia-shvarts-is-an-artist-like-josefmengele-was-a-doctor/

50. Executive Boards of the Reproductive Rights Action League at Yale (RALY) and the Yale Law Students for Reproductive Justice, Letter to the Editor, Yale Daily News, April 21, 2008.

51. Lindsay Beyerstein, "Abortion as art' a hoax?" Majikthise, posted April 17, 2008, (accessed through Newstex/Lexis-Nexis August 6, 2008).

52. This was particularly the case for anti-choice writers, for whom the belief that abortion causes women long-term mental anguish is an increasingly used argument.

53. Rick Rice, Brutally Honest, April 17, 2008. Michelle Malkin tried to lash this budding controversy to the culture wars of twenty years before: "Move over, Andres Serrano and Karen Finley: Here comes bloodsmearing Yale art student Aliza Shvarts," Michelle Malkin, April 17, 2008, http://michellemalkin.com /2008/04/17.

54. "Statement by Yale spokesperson Helaine S. Klasky," Yale University Office of Public Affairs, April 17, 2008, http://opa.yale.edu/news/article.aspx?id=2262; reported in Zachary Abrahamson, Thomas Kaplan, and Martine Powers, "University calls art project a fiction; Shvarts '08 disputes Yale's claim,” Yale Daily News, April 17, 2008. 
The first notable thing is the way this statement plays into Shvarts's hand (to paraphrase the opening lines: she is a liar; we know because she told us so). 55 Not surprisingly, the student countered with a statement of her own, standing by her initial description of her actions over the past nine months, and adding that "no one can say with 100-percent certainty that anything in the piece did or did not happen ... because the nature of the piece is that it did not consist of certainties." This led Yale to re-respond, claiming Shvarts had told the administration that if it reported her admission of the piece's fictiveness, she would deny it. 56

No wonder, then, Yale was so quick to call in the authorities to secure veracity (those "senior officials"), and why that aspect of the university's statement seems more than a little overwrought (not one dean, but two!). This only makes more clear, however, that in parafictions institutional authority is a crucial ingredient in plausibility-whether in the form of the Plexi barriers and neat labels of a historical museum, the convincing slickness of a corporate identity, the digital stationery of an entity like the WTO, or the magic cloak that is, apparently, the business suit.

The Yes Men hijack that authority, but Shvarts claimed no power other than her own. Instead, authorities swooped in to submit a plausible, if disturbing story to the order-restoring category of the hoax. ${ }^{57}$ Or, to try to. According to the university, if she was lying in her initial statements, and had never inseminated herself, then her right to say she had done so was protected as artistic expression. If she was not lying, and had done what she said she did, she would be liable for moral sanction, perhaps treatment. In this situation, only her right to lie was protected.

In a final twist, Shvarts was told that she could exhibit her thesis only if she signed a statement testifying that it was a fiction. This coerced speech act would, of course, have destroyed the piece, which is sited in the state of uncertainty just as much as a sculpture might be specific to a particular physical location. In choosing to name her bleeding as "period," "miscarriage," or "abortion," each person who describes her project demonstrates its central point that what we take as biological facts are constructed in language and ideology. 58 But what

55. Forms of this classic "liar's paradox" are a theme of Rabaté's Ethics of the Lie (see especially ch. 4, "Lies and Paradox," pp. 193-258).

56. "Shvarts, Yale lash over project," Yale Daily News, Friday, April 18, 2008. Shvarts's project can't be securely categorized as a hoax-or even a parafiction-since it remains unclear what was or wasn't true about her story. But it partakes of the parafictional, because the question about veracity is fundamental to its structure.

57. And to fulfill perfectly the role of normative, institutionalized patriarchy the project was designed to challenge.

58. Her statement about the project was published as "Shvarts explains her "repeated self-induced miscarriages," April 18, 2008, at http://www.yaledailynews.com/articles/printarticle/24559. "Because the miscarriages coincide with the expected date of menstruation (the 28th day of my cycle), it remains ambiguous whether there was ever a fertilized ovum or not. The reality of the pregnancy, both for myself and for the audience, is a matter of reading. This ambivalence makes obvious how the act of identification or naming — the act of ascribing a word to something physical—is at its heart an ideological act, an act that literally has the power to construct bodies. In a sense, the act of conception occurs when the viewer assigns the term 'miscarriage' or 'period' to that blood." 
makes her project matter beyond its illustration of this idea is the way this was conflated with the parafictional questions of whether she had done what she said she had, whether an ovum had ever been fertilized, ${ }^{59}$ whether she had lied to the Yale officials. With these, the project mapped the action of the artist controlling her work onto that of a woman controlling her body.

Shvarts refused to sign the statement, ensuring that her project would exist as it does: as a story.

The stories told here involve a diverse range of practices and practitioners, from highly regarded contemporary artists to a student, and from gallery art to tactical media and political activism. They concern a range of somewhat exotic places-Istanbul, Vienna, Sydney, cyberspace, and a uterus-and they vary widely in terms of their complexity, their formal means, their visual languages, and especially the outcomes they seem to favor. Sometimes the revelation of the parafiction is key to the operation. This is when they come closest to simple hoax-but also, to effective activism. Sometimes such a revelation is either withheld or impossible to provide, and this is probably when they come closest to what is conventionally considered art. A complete typology of the parafictional and its tools would tell us much; however, for the time being I want to maintain that the commonalities between these projects tell us at least as much as the differences. Here, then, are some provisional conclusions, or what we might as well call the morals of the stories.

\section{Globalization "Immanence"60}

Nike is a target for culture jammers like 01.ORG not only because of its branding success and ubiquity, but also because it is a corporate-globalization morality tale. ${ }^{61}$ And of course the two sides of the company-its branded identity and its outsourced sweatshops-are connected: the explosion of branding over the last twenty years depends on the loosening up of capital via

59. Theoretically this empirical question could be answered by testing the blood either for a second set of DNA or for the presence of the hormone hCG. But in fact given the limits of testing it would be impossible to say conclusively whether fertilization had occurred or not (leaving aside the question of whether that fact would determine whether or not a life had been conceived). See Melissa Lafsky, "Can Science Get to the Bottom of the Aliza Shvarts Abortion Fracas?," Dicoblog, Discover Web site, http://blogs.discovermagazine.com/discoblog/2008/04/18/can-science-get-to-the-bottom-of-thealiza-shvarts-abortion-fracas/.

60. As indicated below, this term is taken from Pamela M. Lee, "Boundary Issues: The Art World Under the Sign of Globalism," Artforum 42, no. 3 (November 2003); Lee's mobilization of the term "immanence" to discuss art and globalization in turn references Hardt and Negri's Empire, as well as Deleuze and Spinoza.

61. Choosing a specifically American corporation, the faux-takeover of Karlsplatz was structurally and thematically concerned with models of economic imperialism. 
outsourcing. 62 This is something Michael Blum knows well, as the artist is perhaps best known for his 2001 project My Sneakers: a video and installation documenting his negotiation of corporate bureaucracy and layers of sub-contracting in Indonesia in the attempt to meet the workers who had sewn his Nikes. My Sneakers was made on the occasion of an invitation to an artist's residency in Jakarta, and I don't know whether it was in Blum's mind four years later when he went to Istanbul to participate in another ritual of the international art world. But neither of the projects he made on these occasions forgets that art is itself a part of the globalized network of capital. By making his artistic pilgrimage to Jakarta a journey of return for his sneakers, Blum had linked jet-setting and outsourcing in an example of what Pamela M. Lee calls the immanence of the art world to globalization: the way that continent-hopping artists, critics, curators, and collectors participate not just by providing representations of global trade and transit, but substantively: "the activities constitutive of the art world's horizon are indivisible from the activity of globalization itself." 63 Biennials and other international exhibitions are mechanisms for cities or regions to enhance their standing in the global economic order-the Istanbul Biennial has been called "part of broader plans for the marketing of Istanbul as a cultural brand"64_while both careers and art works become organized in terms of travel, shipment, and just-in-time production. Meanwhile, artists negotiate twin pressures to be locally specific and internationally legible. Blum's Safiye Behar project concerns postcolonial subject matter, while the question of EU accession toward which the artist mobilized the story is part of the contemporary process of globalization. And so, of course, is the international Biennial exhibition that was the project's context and reason for being, which Blum kept in play by conceiving the Safiye story specifically for a split audience-local Turkish viewers and international biennial visitors-with a range of educations, languages, and perspectives on Turkish modernity. 65

Parafictioneers produce and manage plausibility. But plausibility (as opposed to accuracy) is not an attribute of a story or image, but of its encounter

62. While the history of brands and branding is generally understood to begin in the nineteenth century, the change in the 1980s through the 1990s is expressed in the term "brand equity" invented in this period (the Wall Street Journal first used the term in 1985). It indicates that the brand-a set of images and associations - is increasingly understood as a primary asset in itself, rather than simply the public face of a company whose value lies in its products and infrastructure. (See Jonathan Knowles, "Varying Perspectives on Brand Equity," Marketing Management (July/August 2008), accessed at www.MarketingNPV.com, March 18, 2009). Klein points out how the new kind of branding connects to the "lightening" of consumer-product companies at this time, as they began to contract out manufacturing processes rather than run their own factories, which in turn depends on trade liberalization. Naomi Klein, No Logo (London: Flamingo, 2001), pp. 4-5, 22-23.

63. Lee, "Boundary Issues," p. 167.

64. Süreyyya Evren, "Parrhesiatic Games in Turkish Contemporary Art Scene," Third Text 22, no. 1, (January, 2008), pp. 35-42, 38. Evren's essay calls for forms of Foucault's parrhesia in contemporary Turkish art. This mode-risky and direct truth-telling-would have a complicated relationship with the parafictional.

65. The project also critically addressed "biennial culture" with the time- and energy-intensive close looking that it required to discern the planted clues to its fictionality. 

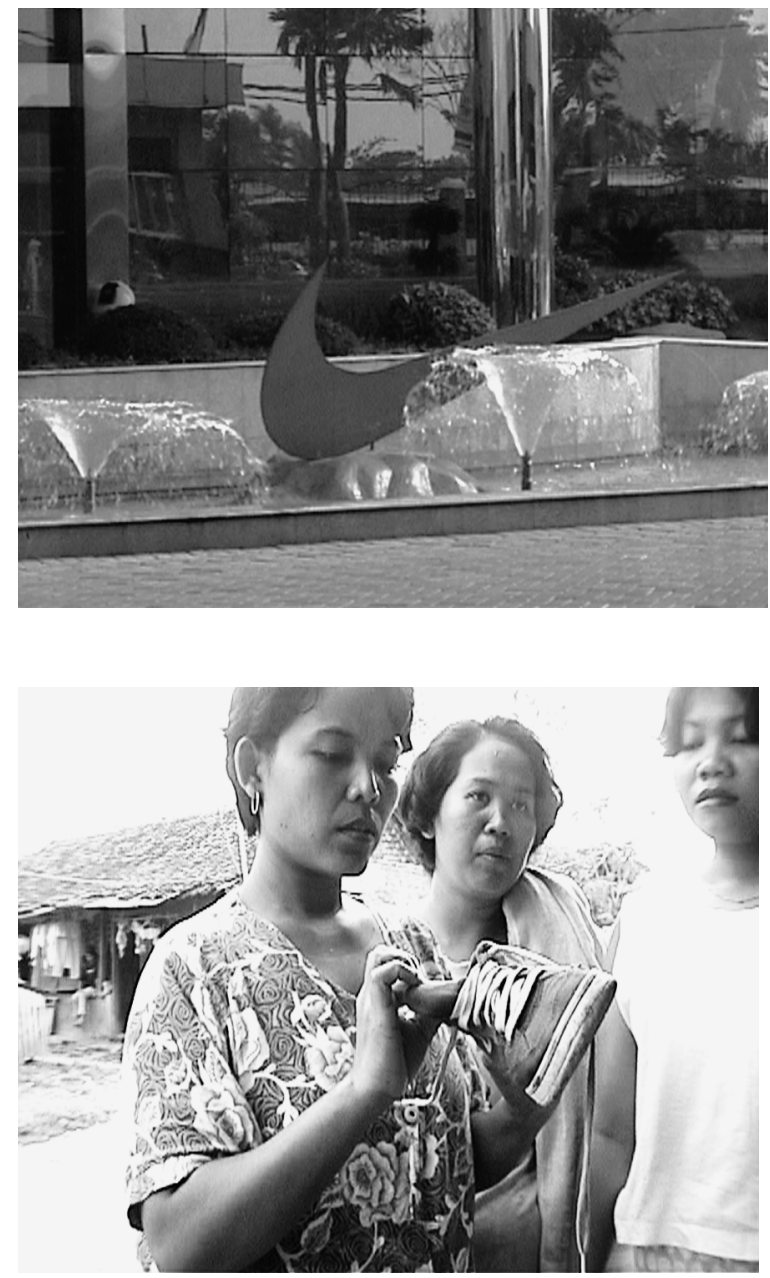

Blum. Two stills from $\mathrm{My}$ Sneakers. 2001.

with viewers, whose various configurations of knowledge and "horizons of expectation" determine whether something is plausible to them. While something similar is true of any artwork-that its meaning is produced in the encounter with the spectator-a parafiction creates a specific multiplicity.

No one has done this more powerfully than The Atlas Group, an organization dedicated to "researching and documenting the contemporary history of Lebanon," particularly the civil wars of 1975-91 (it was also, until recently, the identity under which Walid Raad exhibited most of his art). The first video made for this project was Hostage: The Bachar Tapes (\#17 and 31)_English Version (2000), a testimonial by former hostage Souheil Bachar, who was held by Islamic militants 


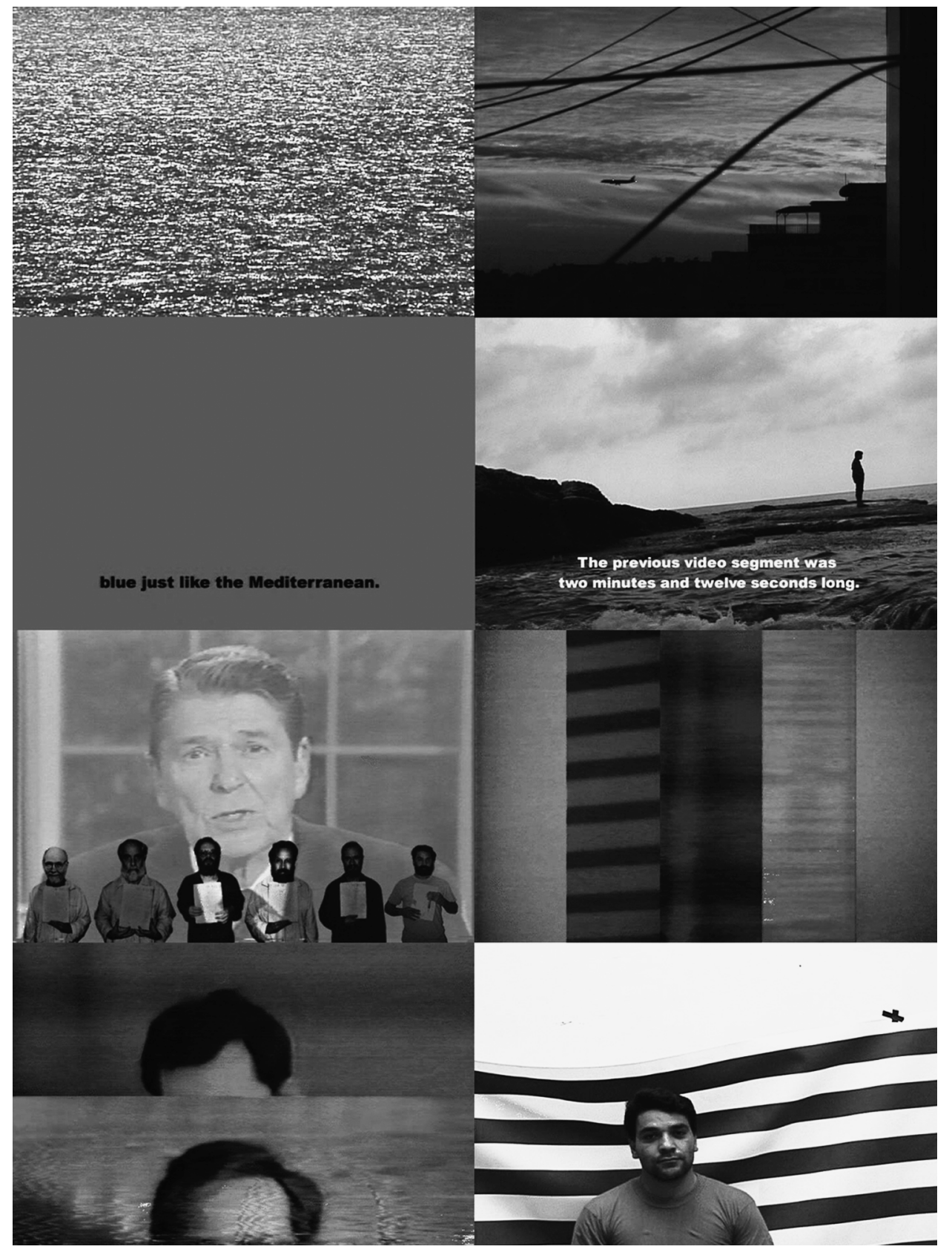

Walid Raad. Hostage: The Bachar

Tapes (\#17 and \#31) English

Version. 2000. CWalid Raad.

Courtesy of the Paula Cooper Gallery. 
in Beirut from 1985 to 1995.66 For some months he shared a cell with Terry Anderson, Benjamin Weir, and three other victims of what became known, here, as the "Western Hostage Crisis." While each of these other prisoners has published a memoir about his hostage experience, this video was the first public documentation of Bachar's. It opens with English text explaining that Bachar made fifty-three testimonial tapes with The Atlas Group, but that "tapes \#17 and \#31 are the only two tapes he makes available for screening outside of Lebanon." We then hear a man's voice introducing himself in Arabic as Souheil Bachar; subtitles translate his words to English.

Like all the documents in The Atlas Group Archive, Hostage crosses the problems of history-writing (the patchiness of documents, the "unreliability" of even first-hand accounts, the work of interpretation that goes into making sense of them); traumatic experience and the ways it both compels and disallows speech; and the particular epistemic conditions of the Lebanese civil war, with its multiplicity of combatant groups, its unreliable sources of information, and its nightmarishly extended duration (indeed historians disagree in determining the year the war "ended"). Onto these, Hostage maps questions of ethnicity, gender, and sexuality, as Bachar (or a woman voicing his words in American-accented English) describes his cohabitation with the Americans, and especially their simultaneous attraction to and repulsion by his body, which culminates in an ambiguously forced sexual encounter in their cell.

Sometimes speaking posed against a jury-rigged cloth backdrop, Bachar's testimony evokes the videotapes of hostages made by their captors. 67 But as if to reverse those coerced speech acts, here the former hostage is at pains to take charge of his testimony. The tape starts with instructions from the subject about its making. Bachar explains how he should be translated: the tapes should be in the official language of the country where they are shown, English for the UK and US, French for France, Arabic for "the Arab world." He is always to be dubbed by a "neutral-toned female voice" (which thereafter chimes in). When he says the subtitles should be in white type on black or "if you prefer... blue like the Mediterranean," he makes it so (performatively): the black background obediently fades to blue.

Bachar not only tells his own stories, but also controls their translation and dissemination. The fact that he allows only two tapes to be shown outside of Lebanon casts these as a message for foreign audiences. This makes it impossible

66. Based in part on Raad's research for his $1997 \mathrm{Ph.D}$. dissertation on the Iran-Contra affair at the University of Rochester, the tape was made during a postdoctoral residency at the American University of Beirut in 1999-2000, and completed in 2000. It was first shown informally in Beirut, and then in experimental video festivals in Europe and the United States (Raad, email to the author, March 12, 2009).

67. The coerced videos haunt his testimony in Hostage's most striking passage: “Tape 31" opens with two minutes, twelve seconds in which all information is withheld except for a silent, screen-filling shot of the rippling surface of a body of water (which is sometimes hard to distinguish from video static). Afterward, Bachar explains that the shot had been the average duration of all the videos he had been forced to make as a captive. 
for the viewer to forget her own geopolitical location-or implication. But the video doesn't assume a homogenous audience. An Arabic speaker will notice that at times the English voiceover expresses something unrelated, or even exactly opposite to Bachar's words. These deviations are not inconsequential: in the silent sexual encounter in their cell, an American tries to penetrate Bachar in the English voiceover, while in Bachar's Arabic the roles are reversed. ${ }^{68}$ In either language, what starts with a mutual pressing of body to body ends in violence, complicating again the video's thematics of autonomy and coercion. The discrepancy between the Arabic and English texts makes that opposition even less simple. Likewise, while Bachar's self-willed, self-narrated, and consummately self-controlled testimonial seems to overturn the logic of the coerced videos of his captivity, the deviations by the voice that literally speaks over his complicate the simple opposition of free speech and forced speech(and though the performative fade from black screen to blue happens as if Bachar's words had willed it, it also introduces the presence of an agent controlling the visualization of the testimony, he who takes the opportunity offered by Bachar's "if you like").

Raad had originally imagined that translation and dubbing would actually be done in different languages when the work was shown in other countries, as stipulated within the video by Bachar, but no matter where the tapes have been shown the voice and subtitles have remained in English, further eroding the illusion of Bachar's authority over his own image as it travels. This introduces more distinctions between viewers (uni-, bi-, and trilingual), and raises the question of English as the global lingua franca. ${ }^{69}$ (It is no coincidence, surely, that in his Istanbul project Michael Blum made Safiye Behar a Turkish-English translator by trade.)

As in Blum's project, in Raad's Hostage the range of positions provided for viewers are at once various and specific. And as in Blum's double address to foreign cultural tourists and to Turkish audiences, the interpellation here breaks down primarily along geopolitical lines. As if to make this clear, Raad cast as Bachar an actor recognizable in Lebanon, giving viewers in that country, or recent expatriates, an immediate hint of fictionality. Non-Lebanese but Arabic-speaking viewers who also speak English have the mistranslations to cue skepticism, while English-only speakers must rely only on the tape's aesthetics and site of viewing to determine whether, how much, and in what details they doubt Bachar's facticity. ${ }^{70}$ Similarly, Raad was known to change the year of The Atlas Group's inception depending on the context and expected audience, from 1999, when he actually

68. Raad, email to the author, March 15, 2009. Raad explains that this difference was intended to complicate "the caricature of the penetrator / the top as the one in charge."

69. Had Safiye Behar existed, she would have been the translator of a poem by Nazim Hikmet that captures something of the status of Bachar's autonomy. What kind of freedom is it that one has, he wondered, when at any moment your country "may be signed over to America." "You and your great freedom / You have the freedom to become an air-base."

70. Though Raad is often quite careful to say that the characters in his Atlas Group work may be fictitious-Hostage is filed in a section of The Atlas Group Archive that its website describes as "files that contain documents that we produced and that we attribute to named imaginary individuals or organizations"- he has been surprised how often viewers take them at face value. 
started working in this vein, to years—-such as 1948, 1967, and 1975-that evoked different turning points in modern Middle Eastern history. In other words, the work alters and is altered depending on geopolitical location.71 But "location" must be understood as more than spatial: it includes the institutional, but also the geographical site in which a viewer sees the work; her location of origin, but also her personal history of dislocations. Such "locations" within and in relationship to institutions, nations, languages, and history determine which aspects of the work are available to a given viewer at a given moment. And this in turn correlates to the spectatorial modes such as disbelief, belief, suspicion, certainty, and doubt that epistemologists call-in what here becomes a pun-“credal states."

With its range of different, shifting, but localized responses, the Bachar video responds to conditions specific to the Lebanese Civil War (with its multiple, shifting factions, its manifold points of view). But also (and without trivializing) it is possible to say that because of this specific multiplicity Hostage and the rest of The Atlas Group work seems also to acknowledge the condition of the art world into which they emerged: one fully enmeshed with globalization, its competing demands for local specificity and global inclusion, and its tensions around legibility, audience, and language. ${ }^{72}$ Fittingly, Hostage first reached wide attention when it was shown at Documenta 11 in 2002. Though created before Raad had achieved this level of international art world recognition, it turns out that his video-coming into and out of credibility differently for viewers depending on their (shifting, multiple) geopolitical locations-was uniquely well-suited to the conditions such an exhibition both assumes and creates.

Internet Epistemology

Caroline Jones has argued that epistemologically complicated recent work such as Raad's performs a crucial service, inculcating a habit of critical doubt in order to counter the atavistic fearmongering that has characterized the "war on terror."73 I largely agree: the experiences of deception and doubt we are put through by parafic-

71. Raad now insists on complicating these terms: "I think it is safe to say that there may have been a time when I thought I knew what I meant by "presumed historical knowledge of the viewers in a given location.' This proposition has become somewhat blurred to me." E-mail to the author, March $15,2009$.

72. It is important here to note-though it is obvious-that "globalization" is not a single process, period, or entity. For instance, very different geo-political and economic pressures are at play in the entry of various regions or nationalities into the "global" contemporary art world (or rather, into visibility for Euro-American art institutions, media, and scholarship).

73. Writing at the height of the Bush-Cheney era in 2003, and trying to diagnose that administration's success in leading a nation past logic and fact into a disastrous and unnecessary war, Jones stresses the coolly cognitive aspects of neo-conceptualist work like Raad's, and the rationality and criticality that its "aesthetics of doubt" encourage in the viewer. I admire this argument but part ways with it slightly (part of the difference is simply that we are not considering exactly the same phenomena-the only case we both discuss is Raad's). Parafiction encourages critical thought, but I believe that in doing so via experiences of discomfort, embarrassment, confusion, and often anger, it refuses to separate the epistemological and the emotional. And I am less confident than Jones that this work can be completely opposed to the culture of deception. 
tional experiments prepare us to be better, more critical information consumers, and therefore citizens. This training relates not only to the culture of fear, however, but to media culture at large, and particularly to the epistemological shock that the rapid mainstreaming of the Internet has caused, especially in the last ten years. ${ }^{74} \mathrm{~A}$ MacArthur Foundation white paper explains that the crucial skills for thriving in our current and coming information environment-the world of Wikipedia and Google - are the ability to distinguish between various sources' levels of reliability and a proclivity to question the transparency of information. ${ }^{75}$ Every webpage created by the Yes Men is an exercise in what, in a different historical context, Michael Leja calls "looking askance"76: the kind of skeptical viewing required when online exploration becomes a primary way of knowing.

However, in this information regime, the challenge is not only to be vigilantly skeptical. As Paul Virilio has said, control operates now not through the censure of true facts, but through the "over-information" surrounding them.77 In the ocean of data we dip into to resolve both looming decisions and passing inquiries (and of course, to investigate parafictions themselves) the problem may be less how to remember to be skeptical, than how to decide when one has been sufficiently so. What is due epistemological diligence? When does one decide that something is-in the epistemologists' phrase now codified as Wikipedia's primary criterion-true enough? It's this, perhaps, that separates the implications of parafiction from stereotypically postmodern assertions of the inaccessibility and relativism of truth or the real. ${ }^{78}$ In experiencing most parafiction-where the fictional hangs on the factual-one is evaluating not only whether a proposition is fictional, but what parts of it are true. (There was indeed an Arab prisoner held along with the Western hostages, it turns out; Mustafa Kemal was in fact an adulterer; but the Aliza Shvartses on Facebook and MySpace are imposters).79 Parafictions train us in skepticism and doubt, but also, oddly, in belief.

74. Though the Internet obviously has a much longer history (ARPANET began operating in 1969) it was after the introduction of the web directory and search engine (Yahoo, 1994) that in the US and Western Europe, at least, it reached something like the level of functionality and participation that it has now, and began to actually, rather than potentially, transform individual, social, and economic life on a mass scale. 1998 is a notable year in this history: it is then that we were introduced to Google, then that Apple debuted the iMac (the first home computer specifically designed with Internet use in mind), and then that weblogs began to appear.

75. Henry Jenkins, with Ravi Rurshotma, Katherine Clinton, Margaret Weigel, and Alice J. Robiso, "Confronting the Challenges of Participatory Culture: Media Education for the 21st Century," (October 19, 2006), The John D. and Catherine T. MacArthur Foundation, available at http://digitallearning.macfound.org/site/c.enJLKQNIFiG/b.2029291/k.97E5/Occasional_Papers.htm, pp. 43-6.

76. See Michael Leja, Looking Askance: Skepticism and American Art from Eakins to Duchamp (Berkeley: University of California Press, 2004).

77. Paul Virilio, Strategy of Deception, trans. Chris Turner (New York: Verso, 2000), p. 48.

78. Most of the practitioners I've been discussing, like myself, came of age intellectually in an environment in which the role of culture in shaping what we take as fact, the ideological drivers and narrative conventions of objective-seeming history, or the inaccessibility of referents among slippery signifiers or interlocking texts were encountered as a kind of common sense. I speculate that the forms they have developed arise from this in some way; but respond also to the zombie versions of these ideas that returned in recent years in forms like "teaching the debate" on evolution, or scorn for "the reality-based community."

79. Aliza Shvarts, e-mail to the author, March 30, 2008. 
Of course the relationship between parafiction and the Internet is not causal-parafiction long predates digital networks. But to do parafiction now is to engage with this condition of communication, knowledge, even cognition. I don't think it is a coincidence that 01.ORG and new-media sponsors Public Netbase picked a structure for their Vienna infobooth that, with its broad windows displaying layered visual and textual information, resembled a kind of walk-in computer monitor. In fact, the infobooth was a customized version of the "Cocobello," a modular structure by Munich-based architect Peter Haimerl, whose vision included multiple booths popping up all around an urban environment, "plugged into the existing communications network," and creating "a network of spaces." 80 Likewise, even though it was not primarily an Internetbased project (nor strictly a hoax), it makes sense that Aliza Shvarts's project shows up in a list of top Internet hoaxes. ${ }^{81}$ Parafiction's natural home is the blog, the discussion board, or the wiki, where information is both malleable in form and material in effect. As it challenges viewers to assess the markers of reliability, then, even a project like Safiye Behar, which had no Internet presence to speak of and took a distinctly pre-digital form, could be considered a kind of live-action experiment in Internet epistemology.

By this I mean that it challenges viewers to assess the forms of informationfrom the font to the URL at the top of the page-with as much care as the content, and that it trains them in both skepticism and belief. But I also mean that it echoes some of the structure of an information economy. The viewer positions in a parafiction are multiple, but they are not equal. The people who have the most knowledge going in, or are the most astute information-interpreters (or, if there is $\mathrm{Wi}-\mathrm{Fi}$, those who are literally well-connected) avoid being duped; and their experience of the piece may include the slightly sadistic fun of watching others in their epistemological struggle. That is to say, the viewers of parafiction are classed. ${ }^{82}$

Parafiction, for Art's Sake

Let's return to A Tribute to Safiye Behar, and step back to wonder: why would anyone believe it in the first place? After all, it wasn't in a history museum, archive, university, or any other site even putatively dedicated to the pursuit of facts and truthfulness. It was in an art show. By all reports most viewers started from the

80. Peter Haimerl, "Cocobello-Mobiles Atelier," Detail 6 (2004), pp. 676-77.

81. Pareene, "5 Bullshit Stories the Whole Internet Fell For," Gawker.com, May 22, 2008. In fact, most bloggers registered the possibility of "hoax" from the beginning. The fact that the story had such powerful resonance even when discussed in the key of "if" is another indication of the way parafiction complicates the distinction between happy and unhappy performative.

82. Class intersects these stories in multiple ways, in fact. For instance, Shvarts's privileged position as an Ivy League student seemed to drive some of the disgust with her project. As Julia Bryan-Wilson has pointed out to me there is also a powerful class component to the Yes Men's hijinks in terms of the viewer's relation to the cast of characters (whether one is positioned closer to the suited experts the Yes Men target and impersonate, or to the workers or the poor who are usually the most immediately impacted by them). 
assumption that the subject was factual, which has to do with Blum's skill, of course-but also with the major movement of art and art history against the notion of art's autonomy. ${ }^{83}$ From real bullet wounds to demonstrations of the financial and political entanglements of artistic institutions, from the production of functional objects to the actual provision of social services, artists in the last century have ceaselessly demonstrated the coextensiveness of art and the real, sloughing off again and again the eighteenth-century distinction between utility and the aesthetic.

But that distinction refuses to go away. It undergirds the Yale statement about Shvarts: had her acts not been art, it concludes, they would have had real consequences. What is elided is the possibility that it was art and she did what she said she did. And this isn't just a matter of lay critics expressing outdated assumptions. The contradiction is built into parafictional art. After all, while the acceptance of art's co-extensiveness with the real explains why Safiye Behar works, it's precisely the opposite idea about art that explains how Blum got away with it. ${ }^{84}$

You can speculate, make up facts, blend different types of facts, or even lie in art because it is understood as a fundamentally frivolous zone. (Of an artist who has produced functional firearms, one magazine breathlessly wonders whether what he is up to is "something . . sinister," or "just art.") 85 It's this attitude that underlies the immediate and recurring accusation lobbed at Shvarts that her project trivialized abortion and miscarriage. As if to literally put your body through the procedure of insemination, to undergo possible termination of pregnancy (however early), to encounter and experience these "issues" in your own physical and mental being, and to repeat all of this for nine months were less serious than, say, writing a term paper about the abortion debate. The project may be many things-dangerous, counterproductive, perhaps even immoral-but trivializing it is not. Yet the fact that it was interpreted this way is in itself telling of the strangely unshakeable assumption that art is a category defined against reality, unencumbered by-and unempowered by-real consequence. Alan Beiber put it perfectly when he asked 01.ORG whether being labeled "artist" was like getting a "jester's license." 86

83. Psychologists also talk about an inherent human "truth bias."

84. Perhaps it is this interrogation of the question of utility rather than the fake Wanted posters, pseudonymns, and so on that links Duchamp to these parafictional practices. See Stephen Wright, "The Future of the Reciprocal Readymade: An Essay on Use Value and Art-Related Practice," Parachute 117 (January-March 2005). Wright's discussion of art and use value in recent collective practice in this essay (based on the catalog essay for his Apexart exhibition "The Future of the Reciprocal Readymade," in Spring 2004) is extremely helpful for thinking about art and politics (as is his term "art-related practice"). The artist and critic Sarah Kanouse has a wonderful phrase for the way art's autonomy is being used in practices similar to these: she calls it art's "tactical irrelevance." Sarah E Kanouse, "Tactical Irrelevance: Art and Politics at Play," paper presented at the Conference of the Union for Democratic Communication, Boca Raton, FL, May 20 2006, at http://www.readysubjects.org /writing/kanouse_artpolitics.pdf.

85. Melissa Milgrom, "Target: AVL," Metropolis (May 2000).

86. "How to provoke today?? Alain Bieber interviews 0100101110101101.ORG on Nike Ground," Rebel:Art Magazine, April 1, 2004, archived copy at http://www.0100101110101101.org /home/nikeground/interview.html. 
The critic Brian Holmes, though, has the metaphor most relevant for the current discussion. In his essay titled "Liar's Poker," he accuses art institutions and politically-engaged artists of playing a bluffing game. The frisson of "relevance" is a type of cultural capital that museums desperately need, and radical artists can provide, he argues, using the example of Documenta to claim that an art institution

must ask its cultural producers for the ace of politics, while proving all the while (with the help of the police, if need be) that this ace is merely a bluff, that it is really a king .... And yet it is through this double game that new symbolic possibilities for conceiving and shaping the ways we live-what Nietzsche might have called "the transvaluation of all values" - can be distributed on the scale that an exhibition like Documenta offers. ${ }^{87}$

Art institutions lie, and turn cultural producers into liars, by asking artists for the winning hand of real politics (the ace), while all the while framing what they do as without consequence (the king). If this is indeed the only way we have to propose new possibilities for living and thinking-for re-distributing the sensible-then this goes a long way toward not only explaining, but justifying the fact that we have seen a rise in parafiction: in art built on the contradictions between art's ability to move into and change the world, and art as a space of only symbolic relevance. Blum, at least, seems to have implicitly recognized something of the kind when he ended the wall text in the Safiye Behar museum this way:

In 2005, as Turkey and the EU are playing liar's poker about their common future, Safiye might prove to be a helpful guiding model for current and future generations. A product of both the East and the West, she stood up for her ideals and devoted a lifetime to what she believed in. She was a global thinker before the term was coined, seeing the world beyond the narrow conceptions of borders, nations, and states.

The "Safiye" in this paragraph might simply be the character of Behar; "guiding model" might refer simply to the progressive ideals to which she devoted her life. But as Blum's winking reference to the politics of deception suggests, it might also be Safiye the exhibition-parafiction itself - that could serve as a guide. What would this mean? Walid Raad has an interesting way of phrasing what art like his can do: "the way an artwork can maintain and work different kind of facts alive [sic] (historical facts; sociological facts, economic facts, emotional facts, aesthetic facts, etc. . . .)." 88 If this destabilizing of "fact" shares a bit more ground than is comfortable with "truthiness," 89 it resonates with Blum's insistence that Safiye is

87. Brian Holmes, "Liar's Poker: Representation of Politics/Politics of Representation," Springeren 1 (2003).

88. Walid Raad, e-mail to the author, March 22, 2009.

89. By registering a generic connection I do not mean to collapse terms. Raad is talking about the proliferation and protection of different kinds of fact, while "truthiness" describes the substitution of one kind of fact for another. 
real to him; with Shvarts's multiplication of the meanings of her body's capabilities, and with the recent effort by scholars such as Bruno Latour to revive a mode of realism, even empiricism, that does not give up on the idea of facts, but rethinks them as matters of investment, debate, and desire. 90 This is precisely the territory of parafiction, which at once reveals the way things are and makes sensible the way we want them to be; and which offers experiences of both skepticism and belief. As for the odd phrasing in the line from Raad, it may be a simple typing error, artifact of a quickly e-mailed response to a critic's question. But how fortuitously the image of working facts alive suits the poetics and politics of the parafictional. The paramedic, after all, doesn't attempt to heal the patient. She resuscitates him, she staunches his bleeding. She keeps pressure on his wounds.

Epilogue: Retracing

Recall the description of viewers in Istanbul "scurrying back" to re-view Blum's installation after learning Safiye was a fiction. The critic's phrase evokes perfectly the temporally extended and multi-phased reception of art that resides in the plausible. But, scurrying? It's what a rodent does. The verb also captures the air of the laboratory that clings to the parafictional, where artists wear the white coats, and viewers run through their mazes. One of the disturbing things about the parafictional is the split between the trap-laying artist and the specifically unwitting viewer, who thinks she is involved in one kind of experience (historical museum; marketing campaign) while actually participating in another (fictionbased installation; cultural critique). When asked why it is so difficult to get a rise out of audiences at their presentations, then, the Yes Men got it exactly right: "Perhaps a rumpled suit would help. Milgram's study suggests that."91

"Scurrying" also expresses the embarrassed, slightly furtive nature of parafictional spectatorship. Being taken in by a parafiction, after all, is not just epistemologically destabilizing. It is humiliating. Think of the audience member who asks a sincere question of a parafictioneering presenter, only to realize later he was one of the few not in on the joke. Or consider the (purely hypothetical) art historian, perhaps in a studio visit with an artist, who nods knowingly about an historical figure before learning that he made her up. Parafiction is an antidote to vanity. It changes you, leaves you both curious and chastened. It also forever changes one's interface with the media, art, museums, and scholarship. The difference is a certain critical outlook, but one that should be differentiated from

90. Bruno Latour, "Why Has Critique Run Out of Steam? From Matters of Fact to Matters of Concern," Critical Inquiry 30 (Winter 2004), p. 231.

91. In Stanley Milgram's behavioral experiments at Yale University in the early 1960s, subjects were told they were participating in a study about learning, when in fact the goal of the experiment was to see how far they would go in inflicting pain on another person when commanded to by a figure in authority (the scientist). 
models of criticality as skepticism. Rancière talks about a "poetics of knowledge" opposed to "critique as suspicion."92 Something like this attitude takes shape, I think, as a post-parafictional alertness to the possibility of play. (Rancière's poetics of knowledge, like the parafictional, "gives value to the effectivity of speech acts”). Art works, lectures, books, exhibitions, and of course journal articles: they shimmer slightly, possibly plausible, plausibly possible.

However, this can be particularly destabilizing for scholarship. No matter

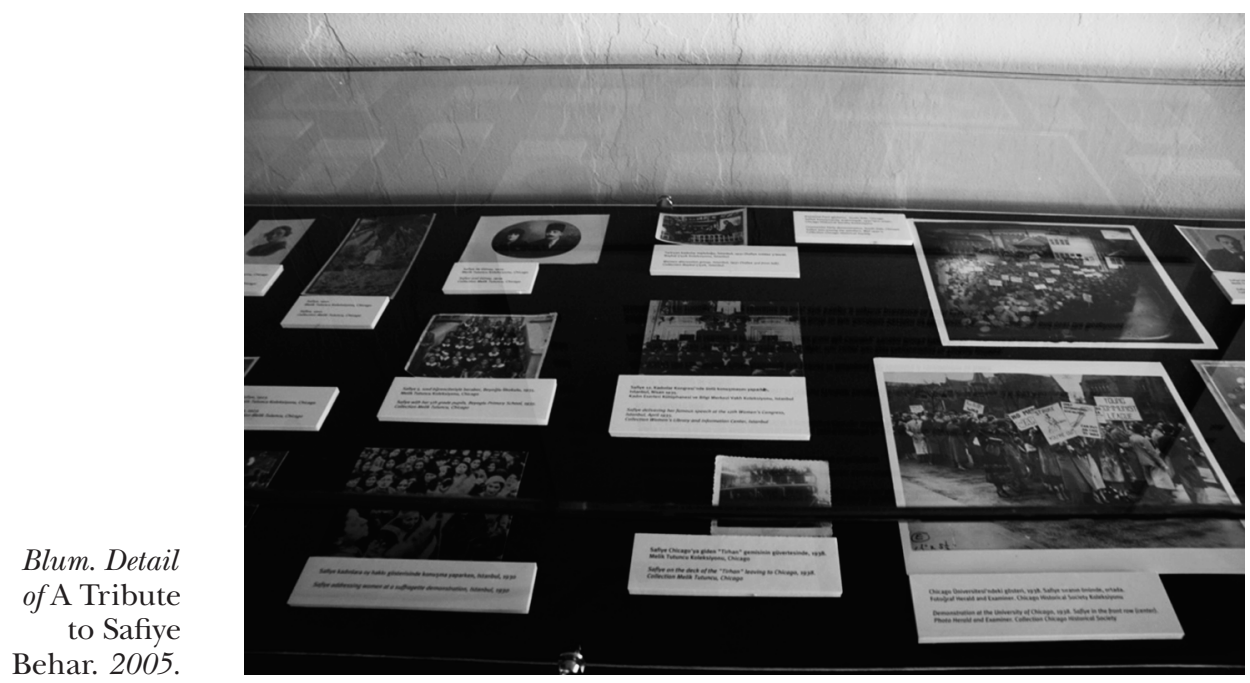

how thoroughly I've researched the stories I've told here, I'm aware of the provisionality of my report. Have I pulled back all the onion-skins of fiction? How much research would be enough? And must I unveil every aspect of the works I've uncovered, if to do so would damage their future functioning? While parafictional art and activism respond to broader areas of cultural practice, it seems imperative to examine their lessons for the endeavor at hand. For the epistemological problems I've been describing don't pertain only to parafictional art. They are the conditions for the enterprise of scholarly study of contemporary art in generalfor this strange practice of trying to think historically about the present. Doing this work we approach the parafictional all the time, relying on memories and stories to build our histories-only a step away from gossip, it sometimes seems. ${ }^{93}$

92. Jacques Rancière and Davide Panagia, "Dissenting Words: A Conversation with Jacques Rancière," Diacritics 30, no. 2 (Summer 2000), pp. 113-16; and Rancière, The Names of History: On the Poetics of Knowledge, trans. Hassan Melehy (Minneapolis: University of Minnesota Press, 1994).

93. For a discussion of scholars' involvement with their subjects, see Julia Bryan-Wilson, "Working It: Contemporary Art, Gendered Labor, and Prostitution," forthcoming in differences: A Journal of Feminist Cultural Criticism 21, no. 2 (Summer 2010). 
Our arguments can function performatively, shaping our subjects' future work, and being shaped by them in turn. Moreover, like the viewer of parafiction, we are always a step behind. Not only because our field is ever-expanding temporally but because, as part of our immanence to globalization, it is growing geographically. We have the responsibility - and feel the pressure - to be ever more inclusive and transnational in our narratives. But, as this paper's Euro-American focus itself demonstrates, few of us have the languages, the cultural knowledge, or the local art-historical background to properly master a fraction of what we would like to think, teach, and write about.

What to do? The subject of parafiction might answer by paraphrasing the pretend Nike Web site. Scholars don't usually wear pressed suits. So why should their scholarship? Why should we stand in the Milgram position? What if contemporary art history were to differ from other parts of the field in owning rather than minimizing some of these contradictions and realities? Walid Raad said in 1989 - maybe - that "facts have to be treated as processes." 94 Acknowledging that no one of us is an authority on the full range of art we need to discuss might encourage us not to narrow our focus but to find ways to research, write, and advise collaboratively. Admitting and even valuing the provisionality of our knowledgeunderstanding that term not only as "subject to alteration" but as in the word "provisions," also-we might find ways for artists to speak within or against our texts. We might develop forms of publication that expect and allow amendment.

We might embolden the mice. Dignify the scurry.

94. Walid Raad, unpublished compilation of statements about The Atlas Group. 